\title{
The Personal Wealth Interests of Politicians and the Stabilization of Financial Markets Ahmed Tahoun ${ }^{1}$ and Laurence van Lent ${ }^{2 *}$
}

\author{
Working Paper No. 52
}

October 19, 2016

\begin{abstract}
We examine whether personal wealth interests affect politicians' decisions about stabilizing financial markets. We use the setting of the government's support of financial institutions under the 2008 Emergency Economic Stabilization Act. We find that the personal wealth interests of politicians are positively associated with voting in favor of the EESA. We implement several analyses to show that personal wealth interests rather than unobservable beliefs in the financial sector explain our result.
\end{abstract}

JEL Codes: D02, D71, D72, G14, G28, G38, P16

Key words: Emergency Economic Stabilization Act, US Congress members, Financial Institutions

\footnotetext{
${ }^{1}$ London Business School, Regent's Park, London, NW1 4SA, United Kingdom atahoun@london.edu

${ }^{2}$ Tilburg University, CentER for Economic Research, PO Box 90153, 5000 LE Tilburg, the Netherlands vanlent@uvt.nl

" Part of this research was undertaken when Ahmed Tahoun was a visiting scholar at the Wharton School and Laurence van Lent was a visiting fellow at the Initiative on Global Markets of the University of Chicago. We thank Arian Borgers, Chung-Yu Hung, Wim Janssen, and Miao Nie for able research assistance. We are grateful for helpful comments from participants at the VII Workshop on Empirical Research in Financial Accounting in Cartagena, and the 2011 American Economic Association annual meeting. We also thank the workshop participants at the University of Amsterdam, the University of Chicago, the University of Mannheim, Lancaster University, LBS, LSE, and Tilburg University; and Daron Acemoglu, Sanjay Bissessur, Tom Ferguson, Tarek Hassan, Harry Huizinga, Valeri Nikolaev, and Sam Peltzman. Ahmed Tahoun acknowledges the financial contribution of the European Commission Research Training Network INTACCT (MRTN-CT-2006-035850).
} 


\section{Introduction}

We use unique, comprehensive data on the wealth of US politicians during the financial crisis of 2008 to document empirically that the personal wealth interests of politicians have a strong association with their vote to rescue financial institutions. The effect of personal wealth interests remains economically meaningful even in the presence of competing interests of voters and special interest groups. This correlation has not yet been documented empirically. We take a first attempt to investigate whether our findings are due to the desire of politicians to protect their wealth or are the outcome of their beliefs in the importance of financial intermediation for the proper working of the economy. Since our data are primarily cross-sectional (which makes it difficult for empiricists to overcome the significant identification challenge associated with this sort of empirical question), our findings have to be interpreted with caution. Nevertheless, our study is the first to document that the stock ownership of politicians is associated with government intervention in (financial) markets.

In our tests, we examine how the personal wealth interests of members of Congress affect their vote on legislative proposals to deal with the deepening financial crisis in September and October of 2008. To illustrate our approach, consider figure 1 that uses data from the House's vote on government intervention on September 29, 2008. The figure is a non-parametric plot of a politician's personal wealth interest (measured by the change in net wealth) against the propensity to vote in favor of intervention. As the percentage loss in net wealth increases, so does the likelihood of supporting the intervention.

We estimate that representatives are almost $60 \%$ more likely to vote in favor of government intervention when the financial crisis affected their personal wealth. We take advantage of our precise empirical measures of both the special interests and the voter interests to tease out the relative importance of a given politician's personal wealth interests in the vote. We find that special interests (as proxied by PAC donations from the financial sector) affect the economic magnitude of the effect of personal wealth interest only when voter opposition is high but not when voter opposition is low. We argue that campaign contributions expose politicians to additional scrutiny by the voters and make them vulnerable to claims that they are acting out of self-interest. Thus, politicians are less able to 
respond to their own personal wealth interests when the voters oppose the government's intervention and when the campaign contributions attract the voters' attention to potential conflicts of interest. In addition, we show that personal wealth interests are more strongly associated with voting when the politicians faced uncontested rather than contested reelections in November 2008. Nevertheless, personal wealth interests remain significant when the incumbent faces opposition. Contrasting contested versus uncontested elections provides another perspective on how important personal wealth interests are in explaining voting behavior in the presence (absence) of competing interests.

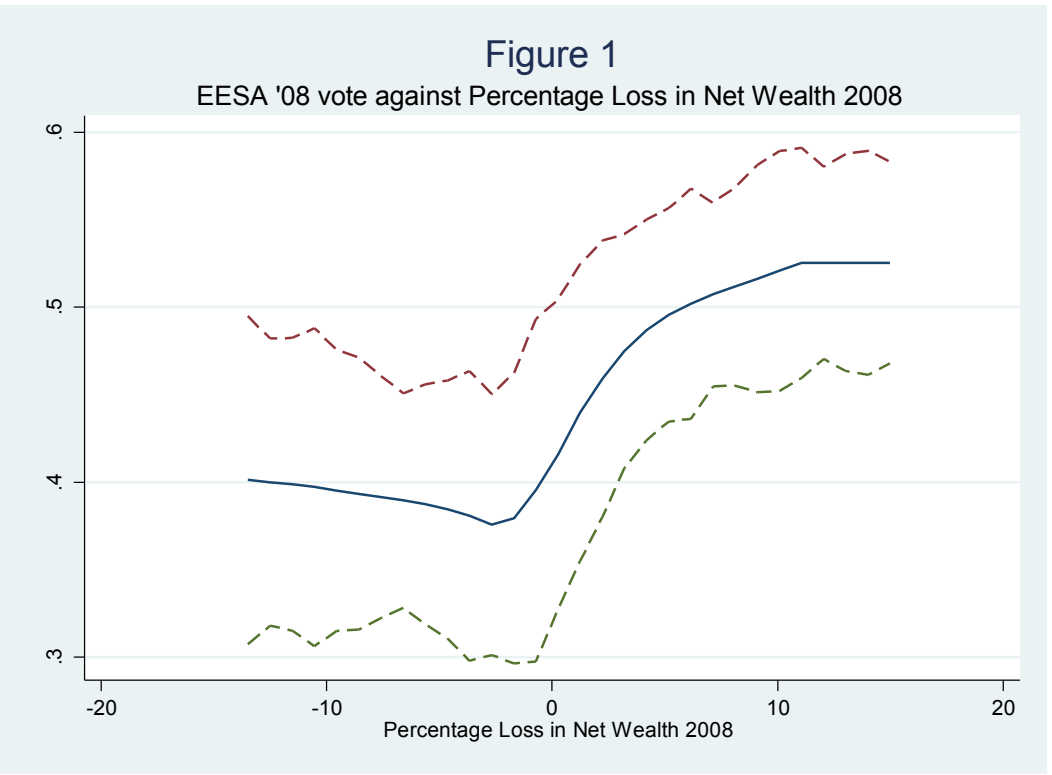

FIGURE 1.-Propensity to vote in favor of the Emergency Economic Stabilization Act (EESA) in the first House roll call on September 29, 2008 against the percentage loss in the representatives' Net Wealth. Negative numbers on the horizontal axis denote the percent gains in net wealth. Data source: The Office of the Clerk of the House and the Center for Responsive Politics. Dashed lines represent the $95 \%$ confidence intervals.

Our results support the prediction that the personal wealth interests of politicians are associated with their voting. We show that personal wealth interests play a role even if the majority of voters oppose the bill. This finding implies that personal wealth interests are an important, but heretofore undocumented factor in voting. We use a range of measures of personal wealth interest, not only to verify the robustness of our findings, but also to recognize the fact that the $2007-2008$ crisis was not just limited to the financial sector, but affected markets broadly, with spillovers to non- 
financial shares, real estate, and bond markets. Thus, the EESA could potentially affect the personal wealth interests of politicians directly or indirectly by preventing their asset holdings from losing value. Thus, our measures of personal wealth interests vary from conservative estimates based on the value of a given politician's asset holdings in the financial sector to comprehensive estimates of changes in net wealth. When analyzing the vote on the EESA, the magnitude of the wealth interests according to the most conservative estimates is relatively small. This begs the question whether politicians' voting can possibly be affected by small amounts of monetary gains. Our position is that the most conservative estimate represents only a lower bound of the potential wealth effects. In addition, prior work on cheating suggest that individuals are willing to do the wrong thing even with relatively small amounts of money at stake (Bhattacharya and Marshall, 2012; Levitt, 2006).

We recognize that asset holdings are endogenous. Individuals who believe that financial intermediation is important hold more stocks in the financial sector. All else equal, those individuals are also more likely to support the government's intervention in the financial sector during a crisis. Thus, an alternative interpretation of our findings is that "finance-friendly" members of Congress support government intervention in the economy. These politicians might be finance-friendly because they have asset holdings that are sensitive to the financial sector and/or because they believe that financial institutions are important for the working of the economy. Our data does not allow us to disentangle these two explanations. Indeed, beliefs and asset holdings are intimately linked and it might be less productive to attempt to artificially tease out the unique effect of each separately. That said, we use several strategies to shed light on the role of beliefs in the financial sector in explaining why politicians might be finance-friendly. For example, we use proxies that are likely to capture a politician's belief in the financial sector that is based on work experience, education, and membership in finance-related congressional committees.

We also use the past investment behavior of politicians to examine the possibility that beliefs in financial intermediation are driving our results. Specifically, as we have data on the history of asset holdings of politicians prior to the EESA vote, we are able to identify a group of politicians who hold assets in the sector before, but crucially, not during the crisis. These individuals are likely to have similar preferences compared with those who continue (or start) to invest in financial sector stocks in 
2008. In particular, ex-investors and current investors are likely to share a belief in the importance of financial intermediation. The two groups, however, differ on one important dimension: whether they (still) own stocks during the crisis and can obtain personal wealth benefits from government intervention in the sector. If the ownership of financial stocks reflects beliefs in financial intermediation, one should not observe any differences in the voting behavior between ex-investors and current investors. If, on the other hand, personal wealth interests drive the voting behavior in favor of the financial sector, we should find that current investors (but not ex-investors) are more likely to vote in favor of the EESA. Our data show that being an ex-investor in the financial sector does not influence voting. Only the asset holdings of current investors are associated with voting.

We also conduct "placebo tests" in which we examine whether being an investor in financial institutions is associated with other votes in the $110^{\text {th }}$ Congress. We find that personal wealth interests are only associated with those votes that can potentially affect a given politician's wealth, but not with other roll call votes, which makes it less likely that personal wealth interests proxy for beliefs.

We then examine a source of variation in personal wealth interests that is unlikely to be related to beliefs in the sector. We consider the participation in a defined contribution pension plan by the spouses of members of Congress. Specifically, we construct a measure of personal wealth interests based on the returns on these plans over 2008. Since returns are exogenous, the variation in returns is arguably uncorrelated with other determinants of voting behavior. In addition, the spouse's choice to participate in a plan is likely to be independent of the politician's beliefs in the sector. Indeed, compelling recent evidence suggests that a substantial part of the variation in investment behavior is genetically determined (Cronqvist and Siegel, 2013). But even if the spouse's holdings were highly influenced by the politician's preference, returns on the spousal plans should not be subject to the same. We document that the returns on the spousal pension plan are strongly associated with the vote on the EESA and interpret this as evidence that personal wealth interests rather than beliefs in the financial sector explain our main result.

Ultimately, our hypothesis is that politicians' voting is associated with their personal wealth interests. Mian et al. (2010) suggest that a politician's vote on the EESA is driven by their ideological position and their electoral prospects. In turn, their reelection probabilities are determined by the 
politicians' ability to convince voters that they cater to the constituency's interests, and by campaign spending, which is determined by their ability to attract special interest contributions. We propose that this voting model be augmented by an additional economically-meaningful factor, i.e., personal wealth interests, which may or may not conflict with either ideology or reelection probabilities. The implication is that when the vote harms a politician's personal wealth and reelection chances and is inconsistent with his or her ideological stance, the probability of supporting the vote is low. On the other hand, when the vote benefits a given politician's personal wealth, but is against his or her ideology or decreases the prospect for reelection, the probability of voting in support of the bill will depend on the relative importance of each factor.

With an eye towards these competing determinants of a politician's vote, we strengthen identification by using nearest neighborhood matching to compare politicians who invest in financial institutions with those who do not. We match on campaign donations and on voter opposition to the EESA as well as (an exact match) on party affiliation and on ideology. We show that investors in financial institutions are more likely to vote in favor of the EESA compared with their matched counterpart who do no hold assets in financial institutions.

The remainder of the paper is organized as follows. Section I summarizes the events of the financial crisis of 2008 and provides a brief literature review. Section II describes the data we use, and Section III presents our main findings on the relation between voting in Congress and the personal wealth interests of politicians. Section IV presents the conclusions.

\section{Legislative Background and Prior Work}

\section{A. The Congressional Response to the Financial Crisis of 2008}

Since August 2007, regulators have attempted to turn the tide of the solvency problems banks faced as a result of the losses from their exposures to subprime mortgages. Despite these efforts, in the summer of 2008, financial market strains intensified as concerns increased that credit losses were mounting (International Monetary Fund, 2008). The US government's intervention to guarantee support to two agencies with a crucial role in the American housing market (Fannie Mae and Freddie Mac) was not sufficient to prevent a firestorm (Acemoglu, et al., 2011). In September 2008, Lehman Brothers submitted a bankruptcy filing that involved significant losses to creditors and counterparties. 
Within days, market pressure forced the merger of Merrill Lynch with the Bank of America and the Federal Reserve (Fed) nationalized the American Insurance Group, the world's largest insurance company. With the liquidity crisis worsening and as banks increasingly lost confidence in the creditworthiness of their counterparts, interbank markets effectively seized up. Massive coordinated liquidity injections by the Fed and other major central banks did little to contain investors' panic.

On September 20, 2008, Treasury Secretary Henry Paulson released a three-page "Legislative Proposal for Treasury Authority to Purchase Mortgage Related Assets." Members of Congress were briefed on the plan in the chambers of House Speaker Nancy Pelosi. At that time the chairman of the Fed, Ben Bernanke offered the stark warning that "If we don't do this, we may not have an economy on Monday." (Sorking, et al., 2008). Two days later, Senator Christopher Dodd advanced a more detailed draft. On September 29, after many negotiations, the House voted on H.R. 3997 that combined Senator Dodd's draft with Mr. Paulson's original proposal. The House rejected the bill, with 205 in favor and 228 against. However, on October 1, 2008, the Senate approved H.R. 1424, by a vote of 74-25 that was an amended version of the bill that would become the EESA. On October 3, the House voted to concur with the Senate on H.R. 1424 and accepted the bill 263 to 171 . That day, the President signed the bill into law as Public Law 110-343 (SigTarp, 2009).

The EESA authorized the $\$ 700$ billion TARP that intended to provide support to US financial institutions by means of the Treasury purchasing or guaranteeing "troubled assets". This support was achieved mainly through the Capital Purchase Program to which $\$ 250$ billion was made available and which intended to invest in "qualified financial institutions" that were deemed financially healthy.

\section{B. Literature Review}

An increasing number of studies use the financial crisis, and in particular the legislative response to it, as a setting to study the behavior of politicians (and their relations with firms). Mian et al. (2010) provide compelling arguments for why the setting is advantageous when examining "the responsiveness of politicians to ... various political and economic factors” (p. 1973). Crises heighten voter interests in political issues and increase the salience of bills. Thus, we can expect constituents to be well informed and motivated to monitor their representative's voting behavior. What's more, voters' interests potentially compete with those of financial institutions. Indeed, Mian et al. (2010) 
show that the campaign contributions from the financial industry affected the voting of the representatives on the EESA, although less so in the case of ideologically conservative members. On a related note, Duchin and Sosyura (2012) and Li (2010) show that politically connected financial institutions are more likely to receive government funding under TARP's Capital Purchase Program. This finding is consistent with a strand of literature which documents that politicians can intervene in the economy and distribute favors to firms in several significant ways such as corporate bailouts, taxation benefits, and the facilitation of access to cheap sources of financing (Claessens, et al., 2008; Faccio, et al., 2006; Khwaja and Mian, 2005).

These prior studies investigate the value of firms' connections to politicians often by using the event study method to take advantage of sudden changes in the value of a connection (Acemoglu, et al., 2016; Akey, 2015; Faccio, 2006; Ferguson and Voth, 2008; Fisman, 2001; Fisman, et al., 2006; Goldman, et al., 2009; Jayachandran, 2006; Johnson and Mitton, 2003; Knight, 2006; Leuz and Oberholzer-Gee, 2006). Other studies use various measures of political connections (usually campaign donations or lobby expenditures). These studies document that firms benefit by higher future stock returns (Borisov, et al., 2016; Cooper, et al., 2010), delayed fraud detection (Yu and Yu, 2008), reduced SEC oversight (Correia, 2009), increased innovation (Reza, et al., 2015), as well as by winning more government contracts (Goldman, et al., 2008; Tahoun, 2014) and experiencing a lower degree of competition in markets (Benmelech and Moskowitz, 2010; Bunkanwanicha and Wiwattanakantang, 2009). On the other hand, some authors argue that connections to politicians carry few benefits and can indicate agency problems (Aggarwal, et al., 2009). Indeed, Kim (2015) documents that firms increase their investments in capital and R\&D after the loss of their political connection.

Our contribution to this literature is to point out that politicians can be connected to firms in a way not considered in most of these earlier studies (however, see Tahoun (2014)). As investors, politicians have an interest in benefiting the firms in which they own stocks even if these firms do not contribute to election campaigns or are otherwise observably connected to a given politician.

Furthermore, the political economy literature has long debated whether members of Congress respond to the economic interests that their electorate or special interests provide (Peltzman, 1976; 
Peltzman, 1984) or whether they are "persons of character" who seek public office to change policy in the public interest (Alesina, 1988; Callander, 2008; Witman, 1977). Yet another possibility is that politicians seek to further their own narrow self-interest as measured by their net wealth just as any other utility maximizing agent would (Besley, 2004; Buchanan, 1989). The empirical evidence on this debate is mixed. For example, Diermeier et al. (2005) show that policy motivations at least partially explain the behavior of politicians; whereas Ferraz and Finan (2008) argue, in contrast, that monetary rewards are the principal motivation for politicians. Our study adds to this literature by arguing that the politician's personal wealth is directly affected by their legislative work inasmuch as their personal assets are intimately linked with the firms that stand to benefit or lose from government intervention.

One extension of this literature considers whether politicians use knowledge obtained in office to trade stocks. The available evidence is mixed, with some studies suggesting that Congress members systematically beat the market index (Ziobrowski, et al., 2011; Ziobrowski, et al., 2004), while others argue that political constraints discourage politicians from trading on their information advantage (Eggers and Hainmueller, 2013). Complementing these insights are the findings in Cohen at al. (2013), who suggest that the voting behavior of politicians whose constituent firms are most affected by pending legislation predicts abnormal returns following the passing of the law. This finding suggests that politicians have a good sense of how their lawmaking affects firms.

More directly related to our study, Tahoun (2014) documents that the asset holdings of members of Congress are related to the campaign contributions of firms; this study suggests a quidpro-quo relation between firms and politicians, facilitated by stock ownership, wherein firms benefit by obtaining more in government contracts. ${ }^{3}$ Whereas Tahoun highlights a channel in which asset holdings are used to forge a relation between firms and politicians, we emphasize a more direct role of these holdings by documenting that a politician's voting can impact on the value of their holdings, which in turn might affect their decision of how to vote.

\footnotetext{
${ }^{3}$ Note that firms may support politicians in multiple ways in addition to campaign donations. For example, they might increase employment for the politicians' voters (Bertrand, et al., 2006). Or connected financial institutions might ease lending conditions for firms in the politician's district (Dinç, 2005).
} 
An innovative aspect of our approach is that we are able to sharply weigh the relative importance of these alternative explanations because we have access to comprehensive data on a politician's personal wealth interests, whereas prior studies have had to rely on compensation flows. We combine this novel dataset with precise measures of voters' interests and of special interests.

\section{Data and Summary Statistics}

\section{A. Data Sources}

Our primary interest is the effect that politicians' personal wealth has on the government's intervention. We use data collected from several sources to investigate this effect. We combine sources about a politician's equity investments, voting behavior and background, as well as election campaign contributions and congressional district data.

To start, we obtain data about the history of asset holdings of members of the $110^{\text {th }}$ Congress from the Center for Responsive Politics for 2004-2008. ${ }^{4}$ According to the Ethics in Government Act of 1978, members of Congress (and Executive Branch officials) are required to file annual reports disclosing their personal finances. Congressional ethics committees enforce and oversee compliance with this requirement. Members of Congress must file Financial Disclosure Report forms that record all assets that are held for investment and worth more than $\$ 1,000$ at year end. Assets held in any selfdirected account or fund must be listed individually, along with their value and the type and amount of income they produce. Assets yielding more than \$200 in annual income must be listed, regardless of their value at year end. Members often report the value of each of their assets within one of several ranges. We use the midpoint of the range as our estimate of that asset's value. When a politician mentions owning an asset but reports its value as "N/A" we view this as a below-disclosure-threshold holding and count the asset as an investment but assign it a zero dollar amount. ${ }^{5}$ They also record income, liabilities, and other sundry items. ${ }^{6}$ These forms must be filed annually by May 15 for the prior calendar year. The Center for Responsive Politics collects these reports from the Senate Office

\footnotetext{
${ }^{4}$ We use the web query on www.opensecrets.org to retrieve the data. The classification of reported assets in the disclosure reports is not always straightforward. We rely on the CRP classification of assets as stock and verify this with the original disclosure reports if their classification is missing or unclear.

${ }^{5}$ This matters in analyses where we use indicator variables that denote investor status (which will take the value of unity for assets values as N/A) and variables that use the dollar amount of investments (which will be zero).

${ }^{6}$ These include contributions made in lieu of honoraria, gifts received, non-governmental positions held, travel that was paid for, and information referring to the member's spouse and dependent children.
} 
of Public Records and the Office of the Clerk of the House. The Center screens each of the listed assets and we populate our database with reported asset holdings in publicly listed financial institutions and in Standard and Poor's 500 (non-financial) companies. We focus on S\&P 500 companies to economize on the costs of hand-collecting the data.

In addition to data on the personal finances of members of the $110^{\text {th }}$ Congress, we also collect data on their voting records from the Office of the Clerk of the House and the Senate Bill Clerk. We supplement this with data on each congressional member's margin of victory in the most recent election from the public records of the Federal Election Commission. Data on the number of terms each politician has served in Congress and whether they are running for reelection in the 2008 is provided in Mian et al. (2010). We obtain biographical data that includes prior employment history from the 2008 edition of Congressional Biographies (part of the official Congressional Directory prepared by the Joint Committee on Printing). ${ }^{7}$ We determine the post-election employment of politicians not returning to Congress using data provided by the Capitol Insiders section of Political Moneyline. ${ }^{8}$ To determine each politician's committee membership in the $110^{\text {th }}$ Congress, we use data collected by Stewart and Woon (2009). ${ }^{9}$

We also require data on the voters' opposition to the government's support of the financial sector as well as on campaign contributions by financial institutions. We obtain voter opinion data from the 2008 edition of the Cooperative Congressional Election Study (CCES) (Ansolabehere, 2011). This data is available at the congressional district level, but was collected after the vote on the EESA (in October-November 2008). We therefore also obtain data from the Pew Research Center, which is based on a survey conducted in September 2008 (i.e., before the voting on EESA) and asks respondents about their views on the government's handling of the burgeoning crisis. We also measure voter interests by considering the constituency's mortgage default rates and the fraction of the voters working in the financial sector. Data from the Mortgage Bankers Association's National Delinquency Survey provides us with state-level data on residential mortgage delinquency and foreclosure rates. We use the data reported in Mian et al. (2010) on the finance employment of voters.

\footnotetext{
${ }^{7}$ Available at: http: www.gpo.gov/fdsys/browse

${ }^{8}$ See: http://www.politicalmoneyline.com/About.aspx

${ }^{9}$ Available at: http://web.mit.edu/17.251/www/data page.html\#1
} 
We obtain data on campaign contributions by Political Action Committees (PAC) associated with financial institutions between 2003 and 2008 from the Center for Responsive Politics, which in turn collects this information directly from the Federal Election Commission. However, we do not use the Center's industry aggregated data, as their definition of the industry of interest "Finance, Insurance and Real Estate" includes companies that were not affected by the EESA.

We use census data on a range of variables describing a politician's district including the percentage of Hispanics and the percentage of people living in an urban environment. ${ }^{10}$

\section{B. Summary Statistics}

Table 1 presents the summary statistics for our variables of interest. These statistics are reported separately for congressional members who are investors in the financial sector and for those who are not. In table 1, the summary statistics for the variables of interest comprise the dollar amount of a representative's asset holdings in the financial sector, the dollar amount of expected losses due to investments in the financial sector, the dollar amount of expected losses in the total stock portfolio, the percentage loss in net wealth during 2008, and the beginning of 2008 dollar amount of net wealth. We calculate each representative's equity investment in the financial sector by adding the disclosed asset holdings in a sample of 555 publicly listed banks, savings associations, bank-holding companies, and savings and loan-holding companies (SIC 6020-6036), as well as life insurance companies (SIC 6310-6319) trading on the NYSE, Amex, or the NASDAQ. ${ }^{11} 12$

To illustrate the economic significance of the asset holdings of members of Congress in the financial sector, consider the following. In 2008, the collective investment of members of the House was between $\$ 23.3$ and $\$ 74.5$ million. About 30\% (namely, 126 out of 434 ) of the representatives invested in financial institutions during 2008. The financial sector constitutes a meaningful fraction in the investment portfolios of politicians; we estimate that the average proportion of asset holdings in

\footnotetext{
${ }^{10}$ These census data are taken from the data supplement in Mian et al. (2010).

${ }^{11}$ Life insurance companies (i.e., members of the American Council of Life Insurers) collectively applied for consideration under TARP (unlike property-casualty insurers, who, through the American Insurance Association, issued a statement that they would not seek government support). Because the Treasury allowed firms to simultaneously apply for government support and acquire a federally regulated bank, life insurance companies satisfied the requirement that only companies with federal regulatory oversight could be considered for support.

${ }^{12}$ Financial asset holdings via mutual or index funds are included if provided in the Center for Responsive Politics database.
} 
the financial sector compared to their holdings in non-financial S\&P500 firms is about 18.5 percent (which is close to the sector weighting in the S\&P500 at about 17.6 percent in 2007).

We compute the expected losses due to investments in the financial sector by multiplying the number of shares a politician holds in financial institutions at the beginning of 2008 by each of these shares' change in stock price on September 29, 2008. We intend this variable to measure the expected losses in the event Congress does not pass the EESA; the losses realized due to the drop in stock prices after the House failed to pass the initial bailout proposal is a reasonable proxy for the same. Note, however, that the losses realized on September 29, if anything, understate the full effect of the event as the market likely anticipated some possibility that Congress could pass the EESA.

A more comprehensive measure of the expected losses considers not only the effect on the value of the investments in the financial sector, but also the effect on other investments in the stock market. Analogous to the expected losses due to investments in the financial sector, we compute the expected losses in the total stock portfolio by multiplying the number of shares a politician holds in financial institutions as well as in nonfinancial S\&P 500 firms by each of these shares' change in stock price on September 29. Asset holdings in the financial sector and in nonfinancial S\&P 500 firms are highly correlated. The correlation between two indicator variables that capture whether a given politician holds assets in the financial sector and in the non-financial S\&P 500, respectively, equals $0.50(p<0.01$, untabulated).

We use the percent change in a politician's net wealth during 2008 as another proxy for the member's wealth-sensitivity to the financial sector. Net wealth is defined as the total assets minus the liabilities reported by politicians in their personal finance disclosures. This particular measure also captures changes in the value of bond and real estate holdings. As a final wealth-sensitivity proxy, which likely constitutes the upper bound of a politician's wealth exposure to the financial sector, we use the dollar amount of the total net wealth (which again includes bond holdings and real estate in addition to equity).

Together, our set of proxies for the personal wealth-sensitivity to the financial sector of politicians covers the spectrum from conservative estimates relying on only the actual investments in financial institutions to more encompassing estimates that use data on the politicians' net wealth and 
might include assets not directly related to financial institutions (but whose value depends on the intervention of the government in the sector). A priori, what motivates the voting behavior of politicians is not clear. But the possibility exists that only direct investments in the financial sector are sufficiently salient to provide personal wealth incentives to members of Congress. On the other hand, politicians might understand that not only their equity investments in the sector might be affected by the vote, but so too their net wealth.

In table 1 , we also list summary statistics for the control variables. Importantly, we provide information on those variables that studies document to affect voting behavior. Specifically, we report a measure of the voters' interests constructed from a question taken from the Cooperative Congressional Election Study (CCES) 2008 (Ansolabehere, 2011) that asks whether the respondent, in principle, supports or opposes legislation on the government's intervention in the financial sector. ${ }^{13}$ We report summary statistics on the percentage of voters at the congressional district who are opposed to the legislation. ${ }^{14} \mathrm{We}$ also report an alternative measure of the voters' interests used in prior work (Mian, et al., 2010), that is, the importance of the financial sector to the representative's congressional district. This variable is defined as the fraction of the district workforce that is employed in the financial activities sector. We also add the number of financial institutions headquartered in the representative's district. In addition, Mian et al. (2010) point out that the change in mortgage default rates between the fourth quarter of 2005 and the same quarter in 2007 captures constituency interests and predicts the vote on the EESA. Our related variable, capturing mortgage defaults rates, is constructed at the state-level.

In addition, we include the total PAC donations made by publicly-listed financial institutions to a politician that we consider a measure of a politician's incentives to respond to the special interests of the financial service industry (Kroszner and Stratman, 1998; Milyo, et al., 2000). We report both a long-term measure of donations that covers total PAC spending between $2003-2008$ as well as campaign donations during the 2007-2008 election cycle (Cooper, et al., 2010).

\footnotetext{
13 The CCES 2008 study explicitly asked a sample of 32,800 respondents about their support for the "U.S. government $\$ 700$ Billion Bank Bailout Plan."

${ }^{14}$ Respondents could also choose "not sure" or could not answer this particular question.
} 


\section{Results}

\section{A. Voting in Congress on Proposals to Provide Support from Government to the Financial Sector}

We first examine whether the personal wealth interests in the financial sector of representatives are associated with their votes on H.R. 3997 and H.R. 1424. We predict that members with higher personal wealth interests are more likely to vote in favor of each of these proposals. Contemporary news reports suggested that at the second vote the leadership of both parties put considerable pressure on the membership to approve the government intervention; for this reason, the politician's incentives might differ between the two votes. ${ }^{15}$

We estimate logit regressions of the propensity that a given politician votes in favor of each of the two legislative proposals. We report the results of these regressions in table 2; columns 1-7 summarize the results for the initial proposal (H.R. 3997), and columns 8-14 for the final bill (H.R. 1424). The dependent variable takes the value of one if a representative votes for the proposal (Yea) and zero otherwise (Nay). We seek to explain variation in voting by differences in personal wealth interests among representatives. Each column in the table reports the results for different measures of personal wealth interests, moving from conservative estimates based on the dollar amount of asset holdings in financial institutions (columns 3 and 8) to more encompassing estimates based on the politicians net wealth (columns 6-7 and 13-14). Note that for variables based on dollar amounts, we use a logarithmic transformation. However, our main specification simply uses an indicator variable that takes the value of one if a politician invests in the financial sector, and zero otherwise (columns 1-2, and 8-9). We include state fixed effects in each but the first regression of each vote (in column 1 and 8) and report robust standard errors in parentheses. ${ }^{16} 17$

The regressions disclose a strong relation between the preferred measures of personal wealth interests and voting in favor of either of the two bills. A representative who is an investor in the

\footnotetext{
${ }^{15}$ http://www.nytimes.com/2008/10/02/business/02bailout.html

16 Clustering standard errors by state does not materially affect inferences, but reduces the number of observations available for estimation.

${ }^{17}$ The number of observations varies across columns. The House represents 435 districts, but at the time of the voting, there was one vacancy (Ohio's $11^{\text {th }}$ district). One representative (G. Weller, R) did not vote on HR 3997 due to "family matters", but did vote on HR 1424. When we include state fixed effects, observations are dropped in those cases where the state indicator perfectly predicts either the yea or the nay votes. Missing data on some of the personal wealth proxies may further reduce the dataset.
} 
financial sector is about $60 \%$ more likely to vote for the government intervention proposal. The predicted probability to vote "Yea" in the initial (final) vote is $67 \%(73 \%)$ for financial sector investors, whereas for non-investors in the financial sector the predicted probability is $41 \%(54 \%)$.

We add a set of controls that intends to capture a politician's voting incentives other than those related to personal wealth. Specifically, consistent with prior research, we add a set of variables that captures the voters' interests in each representative's district as well as a variable that measures the importance of special interest groups in financing the politician's election campaigns. We find that the incentives deriving from the conflicting interests of a given politician's electorate (measured as the percentage of voters in a district who oppose the government's intervention) significantly decrease the likelihood that a representative votes for the proposals in particular in the vote on H.R. 1424. However, this effect is weaker in estimates for the initial bill once we control for state fixed effects, which suggests that state-wide voter sentiment on the initial bailout proposal dominates variation between districts within a state. Measured by the number of financial institutions in a given representative's district as well as by the fraction of the workforce in the financial sector, voter interests seem to play a bigger role in the second vote. We find some evidence, consistent with Mian et al. (2010), that politicians who represent voters from areas with high mortgage default rates tend to support the government intervention more. Mian et al. (2010) measure default rates at the district level and (reflecting their higher precision for this variable) obtain stronger results. We find little evidence that donations by the financial sector to the election campaigns of House members increase their propensity to vote in favor of the initial bill. However, the effect of campaign donations is stronger in the second vote.

We also add a series of controls in each regression that comprises the first dimension of the DW Nominate ideology score of each politician, which measures their conservatism (Poole and Rosenthal, 2007), their party affiliation, the victory margin over the closest competitor in the most recent congressional election, and the number of terms served in Congress (see, e.g., Kau, et al., 1982). We add further controls to reflect whether the representative served on a finance-related committee, is not running for reelection in 2008 , obtains a job in the finance sector after the 2008 election, and for their asset holdings in non-financial stocks. We find that of these political controls, 
the number of terms served (positively) and the Republican Party affiliation (negatively) are associated with the initial vote. We also find that politicians who are not running for reelection are more likely to support the government intervention in both H.R. 3997 and 1424.

Consistent with Mian et al. (2010), we include a range of census controls to capture heterogeneity in the representative's district. In unreported tests, we also control for the gender of politicians as prior studies have documented that women have different investment preferences than men (Barber and Odean, 2001). ${ }^{18}$ Including gender does not change the inferences for our variables of interest and the coefficient on gender never attains significance.

Panel B of table 2 addresses two questions. First, Tahoun (2014) posits that asset holdings in a firm tie a politician's interests to the interests of the firm. This author also suggests that asset holdings are a way for politicians to signal their interest in forming a relation with the firm. Thus, there are at least two different economic channels that are distinct from the (direct) personal wealth effect on the vote, which we propose in this study. To examine whether our findings are merely a manifestation of these earlier described channels or a separate economic force, we compute a measure that captures the elasticity of the politician's asset holdings to campaign donations as suggested in Tahoun (2014). This "investment-PAC sensitivity" is higher when a larger proportion of the politician's assets are explained by PAC donations. We first (in column 1) add this variable to our standard set of controls (including state fixed effects) and show a positive association with the vote on H.R. 3997 (but not with the vote on H.R. 1424 in column 5). We then include our preferred proxy for personal wealth interests (“investor in financial sector") and show that our estimates (in columns 2 and 6 remain very similar in size to what we reported in panel A. In addition, we no longer find a significant effect of the investment-PAC sensitivity on either vote. We conclude from these tests that personal wealth interests have a distinct effect on the vote from those mechanisms described in Tahoun (2014).

Second, our measure of voter opposition to the bailout is based on survey data collected in October-November 2008. Ideally, our measure of voter opposition should reflect opinions of

\footnotetext{
${ }^{18}$ The age of a politician is another potentially important control. We do not include age, however, because it is highly correlated with the politician's number of terms served in office.
} 
constituents before the politicians voted on the EESA. Our alternative proxy is based on opinion data collected before the vote (in September 2008) but it is less precise as it is only available at the state level (for the 48 contiguous states) rather than at the congressional district level. To investigate whether our main results are affected by using post hoc voter opinion data, we report a regression in which we substitute the original district-level voter opinion proxy with the pre-EESA alternative. Specifically, we use two questions from the Pew Research Institute survey ("Based on what you have read and heard, do you think the government is doing an excellent, good, only fair or poor job of handling the financial problems of Wall Street?" and "As you may know, the government is potentially investing billions to try and keep financial institutions and markets secure. Do you think this is the right thing or the wrong thing for the government to be doing?"). Higher scores on these questions imply more voter opposition. We document that our inferences regarding the effect of personal wealth interests are not influenced by the choice of voter opinion proxy (in columns 3-4 and 7-8) in either vote.

\section{B. Isolating Politicians' Wealth-Sensitivity from Preferences for Financial Institutions}

A politician's asset holdings are likely endogenous and reflect unobserved heterogeneity. Consequently, the logit estimations of the relation between the voting behavior and the personal wealth sensitivity to the financial sector might be driven by this heterogeneity rather than by the incentives corresponding to personal wealth. In particular, we need to establish that politicians' preferences for the government's intervention are not systematically related with their preferences to hold stocks (or otherwise expose their personal wealth to the vicissitudes of the financial sector). Unobserved belief in financial institutions causes a correlated omitted variable problem that undermines our ability to attribute our findings on the voting behavior to wealth sensitivity. One way to address this problem is to add the observable characteristics of politicians that are likely related to those unobserved preferences for or belief in the financial sector. An alternative approach, which we use later in this subsection, is to exploit a random source of financial wealth in the politicians' portfolios.

We first use the empirical strategy of adding variables to our main specification that attempt to capture heterogeneity among politicians' preferences for the financial sector. We consider 
politicians who held stock in the financial sector prior to December 2007 (i.e., in any of the years $2004,2005,2006$, and in part of 2007), but no longer owned any stocks in the sector as of January 1 , 2008. We assume that these politicians are likely to share many of the unobserved characteristics with those members of Congress who continued (or started) to own financial sector stocks in 2008. In particular, both should share a belief in the importance of financial institutions. The two groups differ in one important dimension: whether they (still) own stocks during the crisis and can obtain private benefits from the government's support of the sector. There are 56 representatives who are exfinancial sector investors. In part because almost half of these hold the stocks for three years consecutively we assume that these individuals believe in the importance of the sector.

We further add controls for those representatives who have worked in the financial sector before their election to Congress and for those who have obtained a degree in finance or economics. Work experience or educational background might predispose politicians to have stronger preferences for investing in the financial sector as well as for government support of the sector. Next, we add a control for representatives who serve on the House Financial Services Committee, as members of this committee might have stronger preferences for the financial sector than others in the House.

In table 3, panel A, we repeat the main regression specification in columns 1-5 (6-10) for the vote on H.R. 3997 (H.R. 1424), but now add controls for a politician's preferences for the financial sector. We find very little evidence that any of these variables are associated with representatives' voting behavior. Indeed, none of the control variables that capture financial-sector preferences is significantly related to the vote at the conventional levels. Nor is our estimate of the effect of personal wealth sensitivity on the propensity to vote for the intervention significantly affected. In unreported tests, we show that when we drop the indicator variable for being an investor in the financial sector, we still do not obtain a significant association between any of the preference for the financial sector controls. We conclude that our results are not due to multicollinearity between these preferencerelated variables and the variable of interest.

Thus, our principal finding that personal wealth incentives increase the likelihood of a given representative voting in favor of the EESA holds even after conditioning on a wide range of observable characteristics. However, this approach does not completely eliminate the possibility that 
unobservable characteristics drive our results. We compute an informal test statistic, suggested by Altonji, Elber and Taber (2005), to assess how large the effect of "selection on unobservables" would have to be to account for the entire estimate of the coefficient on the proxy for personal wealth sensitivity. To fully explain the coefficient found on the variable "Investor in financial sector" in column 2 of table 2, selection on unobservables would have to be 3.46 times larger than selection on observables.

Next, we turn to an alternative approach to address the source of the omitted variables bias in our main regression. This approach uses a random source of variation in the politicians' wealth. We collect data from the politicians' personal finance disclosure to determine whether their spouses participate in a Defined Contribution (DC) plan. Conditional on the spouse's participation, we compute the annual return over the year 2008 reported on this plan. We multiply the annual return by -1 , to obtain a measure that is increasing in the losses during 2008 , to ease comparison with our prior financial wealth interest proxies. We also compute an indicator variable "DC plan loss" that takes the value of one if the annual return on the spousal pension plan is negative. These two new personal wealth interest measures are arguably uncorrelated with other determinants of voting behavior for two reasons. First, we condition on the spouse's decision to participate in a plan, rather than the politician's. Thus, the participation decision should be independent from the politician's beliefs. Second, returns on pension plans are exogenous, and thus, conditional on participating in the plan, variation in these returns produce a personal wealth interest measure that is unaffected by beliefs.

Table 3, panel B reports the summary statistics of the new personal wealth interest variables. Panel $\mathrm{C}$ presents the results of estimating the main regression specification, but now using the two new personal wealth interest variables. We estimate these logit regressions in the sample of spouses who disclose their participation in DC pension plans $(n=84)$. Given our extensive range of control variables, we do not report results based on state fixed effects estimation. We find a significantly positive relation between the (negative) annual return on the spousal pension plan and the politician's vote for the government intervention on H.R. 3997. Consistent with this finding, we also report a significant positive association between the indicator variable reflecting a loss (i.e., negative annual returns) on the spousal DC plan and the voting behavior. Using this latter variable, we estimate that 
the predicted probability of voting in favor of the EESA is about 23 percent larger for politicians whose spouses report a loss on their plan than for politicians with spouses who disclose positive annual DC plan returns (based on estimates for the largest possible sample). We find similar results for the vote on H.R. 1424 albeit that the estimated effect on the "return on spousal DC plan" is a little smaller in magnitude and only marginally significant $(p=0.13)$.

Our tests, concentrated on the returns on spousal DC plans, exploit a shock to the politician's financial wealth that is unlikely to be correlated with other determinants of voting behavior (such as beliefs in the financial sector). Our evidence is consistent with the hypothesis that personal wealth interests per se, not beliefs, explain the voting on the EESA.

We add two further tests that might help improve identification. We first use nearest neighborhood matching (Abadie and Imbens, 2006; Abadie and Imbens, 2011) to estimate the effect of preferred measure of personal wealth ("Investor in financial sector"). We match politicians based on the campaign donations from financial institutions and the degree of voters' opposition against the EESA in their district. In particular, we want to ensure that the effect of personal wealth interest can be separated from the effect of ideology. We therefore require an exact match on party affiliation as well as a test in which we require that politicians be matched on their ideology (in addition to voter opposition and campaign donations), Our (bias-corrected) estimate of the average treatment effect, reported in panel $\mathrm{C}$ of table 3, equals $0.116(p<0.05)$ when requiring an exact match on party affiliation, which suggest that investors in the financial sector are 11.6 percent more likely to vote in favor of the H.R. 3997 than similar politicians who do not invest in the financial sector. Likewise, when matching politicians on the DW-Nominate ideology score, we find an average treatment effect of $0.131(p=0.02)$. We obtain very similar results for the House vote on H.R. 1424. Together, these results suggest a sizeable effect of being an investor in the financial sector for politicians who are very similar in terms of their ideology and their constituency and special interests.

Second, we examine whether personal wealth interests are associated with other roll call votes during the same Congress. We concentrate on those roll call votes for which we also have data on voter opposition to the legislation in a given representative's district (from the 2008 CCES survey). The resulting set of roll calls span a variety of topics and take place in 2007, i.e., in the first session of 
the $110^{\text {th }}$ Congress. ${ }^{19}$ Consequently, we use information on asset holdings at the start of 2007 in our tests. Our prediction is that our preferred measure "Investor in financial sector" is associated with those roll calls that potentially affect the politician's asset holdings in financial institutions but not with other votes. Using the full set of control variables and including state fixed effects, we find no consistent association between any of these roll calls and our preferred measure. Note that one of these roll calls concerns the extension of NAFTA to include Peru and Columbia. Beliefs in the importance of the financial institutions is plausibly associated with beliefs in free trade. Yet, our personal wealth measure is not associated with the vote in favor of this bill.

\section{Relative Importance of Personal Wealth Incentives}

In this subsection, we examine the question of how important personal wealth interests are relative to politicians' other incentives. In particular, politicians face demands from voters and election campaign contributors that they need to balance against their narrow self-interest if they desire to remain in office for another term. Therefore, personal wealth incentives are strongest in the absence of conflicting interests from voters or from special interests. To test this prediction, we examine how the effect on voting of asset holdings in the financial sector depends on the degree of the voters' opposition against the EESA in the representative's district. Campaign donations from financial institutions can represent their special interests. As both politicians who hold assets in the financial sector as well as donors from the sector presumably would stand to benefit from the EESA, their interests do not necessarily conflict. A priori then, it is not clear if and how the presence of special interest affects the relative importance of personal wealth interests or constituency interests.

We examine this question more closely in a logit regression. We define two regions, that is, "high voter opposition" in which the percentage of voters in a district who oppose EESA is in the top quartile of the distribution, and "low voter opposition" that captures the bottom quartile of the voters" opposition. The baseline category consists of those districts with "moderate voter opposition". We then use our main model of voting behavior and substitute the "percentage voter opposition" variable with two indicators that reflect whether the voters' opposition to the EESA is high or low in a given

\footnotetext{
${ }^{19}$ Specifically, we examine Roll Call vote \# 330, (H.R. 2237), \# 18 (H.R. 2), \# 443 (S. 5 ), \# 437 (H.R. 6304), \# 906 (H.R. 976), \# 832 (H.R. 3221), and \# 1060 (H.R. 3688). The CCES dataset also contains information about voter support for H.J.Res. 88. This roll call, however, took place during the $109^{\text {th }}$ Congress.
} 
representative's district. We interact these two indicator variables with the variable that captures whether a politician holds assets in the financial sector or not. Mindful of Ai and Norton's (2003) warning that coefficients and standard errors in logit regressions are difficult to interpret in the presence of interaction effects, we present our evidence in the form of the marginal effects in table 4 . The probability that a given politician initially votes for the EESA is about 25 percent larger for investors than for non-investors when there is relatively low voter opposition to the $\operatorname{EESA}(p<.01)$ and is about 23 percent larger for investors than for non-investors when there is relatively high voter opposition to the EESA $(p=0.03)$. These two numbers are neither economically nor statistically different from each other $(p=0.88)$. Taken together, these results suggest that voter opposition does not influence the effect of personal wealth interests on voting. Note that in these analyses, we average over campaign contributions when evaluating the marginal effects.

As noted above, personal wealth and special interests appear to be aligned in the EESA vote in the sense that both politicians who hold assets in the sector as well as financial institutions stand to benefit from its adoption. To investigate the interplay between all three interests, we next allow campaign donations to vary. We capture the idea that politicians might face different permutations in the degrees of voter opposition and campaign donations from the financial sector. To preserve power, we divide the sample into four categories based on median splits in the voter opposition and the campaign donations. We compute the interactions between two indicator variables (above median voter opposition and above median PAC contributions) and the indicator variable that captures whether the politician invests in the financial sector.

The augmented regression provides the estimates for the differential marginal effects of being an investor in the financial sector for the four permutations based on the voters' opposition and the campaign donations. We find that the propensity to vote in favor of the EESA is 25 percent higher for politicians who invest in the financial sector than for those who do not $(p=0.02)$ if voter opposition is high and the politician receives below median contributions from the sector. Interestingly, the differential marginal effect on the propensity to vote for is only 15 percent and not statistically different from zero ( $p=0.12)$ when the voters' opposition is high and the representative is a major recipient of contributions from the sector. The difference between these two numbers is economically 
significant but not statistically. Notably, when voters' opposition is low, personal wealth incentives have a similar effect on the propensity to vote for the EESA regardless of PAC donations $(0.18$ for low PAC donations versus 0.16 for high PAC donations). To summarize, together these results suggest that PAC donations affect the economic magnitude of the effect of personal wealth interest only when voter oppositions is high but not when voter opposition is low. One possible explanation may be that receiving high donations from the sector subjects representatives to additional public scrutiny; politicians might well want to avoid public outcry should they be seen to profit personally from the EESA as well as receive campaign support money from the financial sector.

In unreported tests, we use data on whether an incumbent faces an uncontested re-election in November 2008. Uncontested elections reduce pressures on politicians to vote according to the wishes of special interests and constituents. As they run unopposed, these incumbents do not have to cater to their constituency's preferences because even if they support unpopular policies the electoral backlash will be small. Similarly, uncontested incumbents rely less on campaign donations from special interests. By contrasting contested versus uncontested elections, we provide another perspective on how important personal wealth interests are in explaining voting behavior in the presence (absence) of competing interests.

We interact the indicator variable for asset holdings in the financial sector (i.e., our preferred personal wealth sensitivity measure) with an indicator variable that takes the value of one for representatives who are uncontested in the upcoming election. We compute the marginal effects from the personal wealth sensitivity and show that the propensity to vote in favor of the EESA is 32.3 percent higher for politicians who hold assets in the financial sector than for those who do not in the group of uncontested elections $(p=.07)$. In contested elections, the differential propensity to vote in favor between investors and non-investors equals, in contrast, to 18.5 percent $(p<.01)$. We conclude from this finding that when voter incentives are weak, the correlation between personal wealth interest and the vote is substantial. However, even when competing (i.e., voter) interest are present, personal wealth interest continue to be significantly correlated with voting by politicians.

D. The Senate Vote on H.R. 1424 
We have highlighted the House vote in our tests thus far. We have done so for three reasons. First, the Senate vote on October 1, was much different from the initial House vote because in the intervening days it became increasingly clear what the economic consequences might be if Congress were not to approve the bill. Senators were very much involved in crafting a "package" that would have sufficient bi-partisan support when the proposal was put to the vote in the Senate. In all, individual members likely experienced less leeway to depart from approved party policy (Hitt and Lueck, 2008). Thus, personal wealth interests would have to be strong to dominate these political realities. Second, some earlier studies suggest that senators, more than House members, are driven by policy preferences and not by electoral or special interests (Diermeier, et al., 2005). If so, then we would not necessarily expect personal wealth interests to matter much. Further, as Mian et al. (2010) point out, the sample for the senate is smaller than for the House, which potentially reduces the power of our tests. For this reason, we conduct the tests for the Senate using a limited set of control variables, which include the percentage of voters opposing bank bailouts in the state, the (logarithm of) long term PAC donations by the financial sector, as well as the party affiliation of senators, their seniority, the victory margin in the previous election, and whether they have asset holdings in the nonfinancial sector.

In unreported tests, we find the log of net wealth is positively associated with the vote, the estimate of $0.32(z=1.95)$, corresponds with an average marginal effect of approximately $0.05(z=$ 2.15). This finding implies that a one-standard deviation change in the log of net wealth increases the propensity to vote in favor of the bill by about 8 percent. We do not find, however, a significant correlation between personal wealth interests and the vote for the remaining proxies. Notwithstanding these findings, the possibility exists that personal wealth interests under specific conditions are correlated with voting. We examine this possibility by conditioning the relation on the voters' opposition against the EESA in each state. Specifically, we compute the marginal effects of the personal wealth interests by using the indicator measure of whether a senator holds assets in the financial sector on the Senate vote for the states with high voter opposition and for the states with low voter opposition. We find that the marginal effect of personal wealth interests is $0.15(p=0.07)$ for senators who face voters with little opposition and $-0.09(p>0.10)$ for those representing states in 
which voters strongly oppose the EESA. Thus, the propensity to vote in favor in the Senate increases with higher personal wealth interests when other incentives are not too strong.

\section{E. Robustness: Transaction Data}

We use data on the 2008 opening balance of asset holdings of members of Congress to compute our personal wealth sensitivity proxies. Because the first vote did not take place until September $29^{\text {th }}, 2008$, the possibility exists that members divested their holdings or bought more stock in financial institutions in the months before the votes. If so, then our proxies based on the opening balance would not be very clean. We use transactions data from the Financial Disclosure Report to reconstruct the portfolio holdings of each politician on each of the voting days (i.e., September $29^{\text {th }}$, October $1^{\text {st }}$, and October 3,2008$)$. We then check the sensitivity of the results reported in table 2 to the use of the modified proxies. We find very much the same results and none of the inferences are changed. That said, these transaction data are not very clean. Politicians, for example, do not always report the date on which a purchase or sale occurred. For a significant proportion of transactions, then, we cannot be sure whether they occurred before or after the roll call on the bailout proposals. For this reason, we use the beginning balance holdings data for our main tests.

\section{Conclusion}

In this paper, we exploit a new dataset with details on the personal wealth of members of Congress to demonstrate that politicians' personal wealth interests are correlated with their voting behavior. In particular, we use this dataset to document voting behavior on key legislative proposals to provide the government's support to the financial sector during the crisis of 2008. Although prior studies document that politicians respond to the interests of their constituency and pressure groups, it has gone virtually unnoticed that they are also investors. As investors, part of their wealth rests with firms whose wellbeing falls under their legislative influence.

We show that personal wealth interests are an important factor in the voting behavior of politicians by examining the impact of personal wealth in settings with varying degrees of competing interests from voters and special interest groups. We report that personal wealth interests are economically meaningful in explaining a given politician's behavior even when the voters strongly oppose the government's intervention. 
Through a range of tests, we address the possibility that our results are explained by politicians' unobservable preferences for the sector. Although perhaps no single one of these tests provides conclusive evidence, together our findings suggests that wealth interests rather than beliefs explain politicians' voting. In particular, we examine the effect of ideology and show that when matched on ideology or (exactly) on party affiliation, the impact on voting of having assets in the financial sector or not remains substantial. Thus, we conclude that ideology and personal wealth are distinct determinants of politician behavior, which is consistent with the findings of Stewart (2015).

Congress recognizes that politicians might use their office to further their personal finances. Doing so is not necessarily illegal. Indeed, federal law defines a conflict of interest quite narrowly and, in general, cases in which politicians support a decision that yields personal financial benefits do not qualify as conflicts of interest as long as the decision benefits many, and not just the member in question (Committee on Standards of Official Conduct, 2008). The House ethics manual even states that "Members of Congress frequently maintain economic interests that merge or correspond with the interests of their constituents. This community of interests ... is therefore inevitable and unavoidable" (Committee on Standards of Official Conduct, 2008, p. 251). However, we show that personal financial interests also explain voting behavior when the interests of voters and representatives conflict. Former House Speaker Nancy Pelosi has argued "when there's a thought of conflict of interest between a member's financial holdings and the government bailouts then the member should divest". A number of high-profile ethics violations emphasizes that at least some constituencies might not be well represented despite this advice. ${ }^{20}$ Congress recently approved the Stop Trading on Congressional Knowledge Act aimed to prevent members from taking advantage of non-public information gleaned from their activities as legislators. There is currently little evidence that members of Congress are indeed able to profit from confidential information (Ziobrowski, et al., 2004), but our paper shows that a more direct way is available to politicians to protect their financial interests through their office. And thus while we refrain from drawing direct welfare implications from our results, we do note that strong political institutions are necessary for keeping representatives accountable to their voters and for preventing the abuse of power (Querubin and Snyder, 2013).

${ }^{20}$ See, e.g., the cases of Representatives Maxine Waters and Spencer Bachus. 
Accountability, in turn, requires that voters have sufficient information about what explains a politician's actions (Besley and Prat, 2006). Our study suggests that constituents need to pay attention to the asset holdings of their representatives in relation to their work in Congress. 


\section{References}

Abadie, A. and Imbens, G.W. (2006) Large sample properties of matching estimators for average treatment effects, Econometrica, 74, 235-267.

Abadie, A. and Imbens, G.W. (2011) Bias-corrected matching estimators for average treatment effects, Journal of Business \& Economic Statistics, 29.

Acemoglu, D., Johnson, S., Kermani, A., Kwak, J. and Mitton, T. (2011) The value of political connections in the United States. in, Working paper, MIT.

Acemoglu, D., Johnson, S., Kermani, A., Kwak, J. and Mitton, T. (2016) The value of connections in turbulent times: Evidence from the United States, Journal of Financial Economics, 121, 368-391.

Aggarwal, R.K., Meschke, F. and Wang, T. (2009) Corporate political contributions: investment or agency? in, Working-paper, University of Minnesota.

Ai, C. and Norton, E.C. (2003) Interaction terms in logit and probit models, Economic Letters, 80, 123-129.

Akey, P. (2015) Valuing Changes in Political Networks: Evidence from Campaign Contributions to Close Congressional Elections, Review of Financial Studies, 28, 3188-3223.

Alesina, A. (1988) Credibility and Policy Convergence in a 2-Party System with Rational Voters, American Economic Review, 78, 796-805.

Altonji, Joseph G., Elder, Todd E. and Taber, Christopher R. (2005) Selection on Observed and Unobserved Variables: Assessing the Effectiveness of Catholic Schools, Journal of Political Economy, 113, 151-184.

Ansolabehere, S. (2011) CCES Common Content, 2008. in., YouGov.

Barber, B.M. and Odean, T. (2001) Boys will be boys: Gender, overconfidence, and common stock investment, The Quarterly Journal of Economics, 116, 261-292.

Benmelech, E. and Moskowitz, T.J. (2010) The political economy of financial regulation: evidence from US state usury laws in the 19th century, Journal of Finance, 65, 1029-1073.

Bertrand, M., Kramarz, F., Schoar, A. and Thesmar, D. (2006) Politicians, firms and the political business cycle: evidence from France, Unpublished working paper. University of Chicago.

Besley, T. (2004) Paying politicians: theory and evidence, Journal of the European Economic Association, 2, 193-215.

Besley, T. and Prat, A. (2006) Handcuffs for the Grabbing Hand? Media Capture and Government Accountability, The American Economic Review, 96, 720-736.

Bhattacharya, U. and Marshall, C.D. (2012) Do they do it for the money?, Journal of Corporate Finance, 18, 92-104.

Borisov, A., Goldman, E. and Gupta, N. (2016) The Corporate Value of (Corrupt) Lobbying, Review of Financial Studies, 29, 1039-1071.

Buchanan, J. (1989) The public choice perspective. in, Essays on political economy. University of Hawaii Press.

Bunkanwanicha, P. and Wiwattanakantang, Y. (2009) Big business owners in politics, Review of Financial Studies, 22, 2133-2168.

Callander, S. (2008) Political motivations, Review of Economic Studies, 75, 671-697.

Claessens, S., Feijen, E. and Laeven, L. (2008) Political connections and preferential access to finance: The role of campaign contributions, Journal of Financial Economics, 88, 554-580.

Cohen, L., Diether, K. and Malloy, C. (2013) Legislating stock prices, Journal of Financial

Economics, 110, 574-595.

Committee on Standards of Official Conduct (2008) House Ethics Manual. Washington.

Cooper, M., Gulen, H. and Ovtchinnikov (2010) Corporate political contribution and stock returns, Journal of Finance, 65, 687-724

Correia, M.M. (2009) Political connections, SEC enforcement and accounting quality. in, Working paper, Stanford University.

Cronqvist, H. and Siegel, S. (2013) The genetics of investment biases, Journal of Financial Economics, in press.

Diermeier, D., Keane, M. and Merlo, A. (2005) A political economy model of congressional careers, American Economic Review, 95, 347-373. 
Dinç, I.S. (2005) Politicians and banks: Political influences on government-owned banks in emerging markets, Journal of Financial Economics, 77, 453-479.

Duchin, R. and Sosyura, D. (2012) The Politics of Government Investment, Journal of Financial Economics, 106, 24-48.

Eggers, A. and Hainmueller, J. (2013) Capitol Losses: The Mediocre Performance of Congressional Stock Portfolios, The Journal of Politics, 75, 535-551.

Faccio, M. (2006) Politically connected firms, American Economic Review, 96, 369-386.

Faccio, M., Masulis, R.W. and McConnell, J.J. (2006) Political connections and corporate bailouts, Journal of Finance, LXI, 2597-2635.

Ferguson, T. and Voth, H.-J. (2008) Betting on Hitler: the value of political connections in Nazi Germany, The Quarterly Journal of Economics, 101-137.

Ferraz, C. and Finan, F. (2008) Motivating Politicians: The Impacts of Monetary Incentives on Quality and Performance, SSRN eLibrary.

Fisman, R. (2001) Estimating the value of political connections, American Economic Review, 91, 1095-1102.

Fisman, R., Fisman, D., Galef, J. and Khurana, R. (2006) Estimating the value of connections to vicepresident Cheney. in, Working Paper, Columbia University.

Goldman, E., Rocholl, J. and So, J. (2008) Political connections and the allocation of procurement contracts. in, Working paper, Indiana University.

Goldman, E., Rocholl, J. and So, J. (2009) Do Politically Connected Boards Affect Firm Value?, Review of Financial Studies, 22, 2331-2360.

Hitt, G. and Lueck, S. (2008) Senate vote gives bailout plan new life. in, The Wall Street Journal. New York.

International Monetary Fund (2008) World Economic Outlook: Financial stress, downturns, and recoveries. in., Washington, DC.

Jayachandran, S. (2006) The Jeffords Effect, Journal of Law and Economics, 49, 397-425.

Johnson, S. and Mitton, T. (2003) Cronyism and capital controls: evidence from Malaysia, Journal of Financial Economics, 67, 351-382.

Kau, J.B., Keenan, D. and Rubin, P.H. (1982) A general equilibrium model of congressional voting, Quarterly Journal of Economics, 97, 271-293.

Khwaja, A.I. and Mian, A. (2005) Do lenders favor politically connected firms? Rent provision in an emerging financial market, Quarterly Journal of Economics, 120, 1371-1411.

Kim, T. (2015) Does a firm's political capital affect its investment and innovation. in U.o.N. Dame (ed), Working Paper.

Knight, B. (2006) Are policy platforms capitalized into equity prices? Evidence from the Bush/Gore 2000 Presidential Election, Journal of Public Economics, 90, 751-773.

Kroszner, R.S. and Stratman, T. (1998) Interest-group competition and the organization of Congress: Theory and evidence from financial services' Political Action Committees, American Economic Review, 88, 1163-1187.

Leuz, C. and Oberholzer-Gee, F. (2006) Political relationships, global financing, and corporate transparency: Evidence from Indonesia, Journal of Financial Economics, 81, 411-439.

Levitt, S.D. (2006) White-Collar Crime Writ Small: A Case Study of Bagels, Donuts, and the Honor System, The American Economic Review, 96, 290-294.

Li, L. (2010) TARP funds distribution and bank loan growth. in, Working paper, Boston College.

Mian, A.R., Sufi, A. and Trebbi, F. (2010) The Political Economy of the U.S. Mortgage Default Crisis, American Economic Review, 100, 1967-1998.

Milyo, J., Primo, D. and Groseclose, T. (2000) Corporate PAC campaign contributions in perspective, Business and Politics, 2, 5-14.

Peltzman, S. (1976) Towards a more general theory of regulation?, Journal of Law and Economics, $19,211-241$.

Peltzman, S. (1984) Constituent interest and congressional voting, Journal of Law \& Economics, 27, 181-210.

Poole, K.T. and Rosenthal, H. (2007) Ideology and congress. Transaction Press, Piscataway, NJ. 
Querubin, P. and Snyder, J.M. (2013) The Control of Politicians in Normal Times and Times of Crisis: Wealth Accumulation by U.S. Congressmen, 1850-1880, Quarterly Journal of Political Science, 8, 409-450.

Reza, S.W., Ovtchinnikov, A.V. and Wu, Y. (2015) Political Activism and Firm Innovation, Available at SSRN 2703365.

SigTarp (2009) Quarterly report to congress. in.

Sorking, A.R., Henriques, D.B., Andrews, E.L. and Nocera, J. (2008) As credit crisis spiraled, alarm led to action. in, The New York Times. New York.

Stewart, B. (2015) Personal Wealth and Legislator Voting Ideology.

Stewart III, C. and Woon, J. (2009) Congressional committee assignments, 103rd to 110th Congresses, 1993-2007: [House and Senate], [Updated to 01/03/2009]. in.

Tahoun, A. (2014) The role of stock ownership by US members of Congress on the market for political favors, Journal of Financial Economics, 111, 86-110.

Witman, D.A. (1977) Candidates with policy preferences: a dynamic model, Journal of Economic Theory, 14, 180-189.

$\mathrm{Yu}, \mathrm{F}$. and $\mathrm{Yu}, \mathrm{X}$. (2008) Corporate lobbying and fraud detection. in, Working paper, Indiana University.

Ziobrowski, A.J., Boyd, J.W., Cheng, P. and Ziobrowski, B.J. (2011) Abnormal returns from the common stock investments of members of the US House of representatives, Business and Politics, 13, Article 4.

Ziobrowski, A.J., Cheng, P., Boyd, J.W. and Ziobrowski, B.J. (2004) Abnormal returns from the common stock investments of the US Senate, Journal of Financial and Quantitative Analysis, 39, 116. 
TABLE 1

SUMMARY STATISTICS

\begin{tabular}{|c|c|c|c|c|c|c|}
\hline & Mean & Median & $\begin{array}{l}\text { Standard } \\
\text { Deviation }\end{array}$ & Mean & Median & $\begin{array}{l}\text { Standard } \\
\text { Deviation }\end{array}$ \\
\hline & \multicolumn{6}{|c|}{ Members of the House, $\mathrm{N}=434$} \\
\hline & \multicolumn{3}{|c|}{ Investors in financial sector } & \multicolumn{3}{|c|}{ Non-Investors in financial sector } \\
\hline Yea vote on H.R. $3997^{\#}$ & 0.58 & 1.00 & 0.50 & 0.43 & 0.00 & 0.50 \\
\hline Yea vote on H.R. $1424^{\#}$ & 0.70 & 1.00 & 0.46 & 0.57 & 1.00 & 0.50 \\
\hline \multicolumn{7}{|l|}{ Measures of personal wealth interests } \\
\hline Equity investment in financial sector $(\times \$ 1,000)$ & 388.06 & 32.84 & 1803.34 & - & - & - \\
\hline Expected losses due to investment in financial sector $(\times \$ 1,000)$ & 40.34 & 4.46 & 177.82 & - & - & - \\
\hline Expected losses due to participation in stock market $(\times \$ 1,000)$ & 175.95 & 13.25 & 735.21 & 1.60 & 0.00 & 12.43 \\
\hline Percentage loss in net wealth in $2008^{\S}$ & 13.41 & 11.71 & 33.55 & -15.46 & 2.63 & 85.43 \\
\hline Net wealth at the beginning of $2008(\times \$ 1,000)$ & 12223.87 & 2306.25 & 41816.23 & 2651.70 & 489.76 & 19815.58 \\
\hline \multicolumn{7}{|l|}{ Measures of voter interest } \\
\hline Percentage voters opposed to bank bailout (district) & 72.72 & 74.51 & 9.41 & 71.92 & 73.84 & 9.51 \\
\hline Fraction of workforce employed in financial sector (district) & 5.01 & 4.41 & 2.07 & 4.90 & 4.43 & 2.02 \\
\hline Number of financial institutions (district) & 1.29 & 1.00 & 1.48 & 1.06 & 1.00 & 1.36 \\
\hline Change in mortgage default rates 2005Q4-2007Q4 (state) & 0.91 & 1.12 & 2.07 & 1.21 & 1.19 & 1.94 \\
\hline \multicolumn{7}{|l|}{ Measures of special interest (election campaign contributions) } \\
\hline Long-term PAC donations by financial sector $(\times \$ 1,000)$ & 46.21 & 25.50 & 56.60 & 37.23 & 14.00 & 61.57 \\
\hline Election cycle $2006-08$ PAC donations by financial sector $(\times \$ 1,000)$ & 19.77 & 8.00 & 26.13 & 15.55 & 4.55 & 26.70 \\
\hline
\end{tabular}


Political controls

DW Nominate ideology score

Party affiliation is republican ${ }^{\#}$

Victory margin previous election

Number of terms served

Finance committee member ${ }^{\#}$

Post-congress work in finance sector

Not running for reelection ${ }^{\#}$

Equity investor in non-financial sector ${ }^{\#}$

Finance-related education ${ }^{\#}$

Previous employment in financial sector ${ }^{\#}$

$\begin{array}{rrrrrr}0.05 & -0.13 & 0.48 & 0.02 & -0.19 & 0.52 \\ 0.47 & 0.00 & 0.50 & 0.46 & 0.00 & 0.50 \\ 33.16 & 30.00 & 24.82 & 36.64 & 32.00 & 26.78 \\ 6.14 & 6.00 & 4.61 & 5.93 & 5.50 & 4.31 \\ 0.21 & 0.00 & 0.41 & 0.16 & 0.00 & 0.37 \\ 0.15 & 0.00 & 0.36 & 0.11 & 0.00 & 0.32 \\ 0.06 & 0.00 & 0.23 & 0.06 & 0.00 & 0.23 \\ 0.79 & 1.00 & 0.41 & 0.24 & 0.00 & 0.43 \\ 0.20 & 0.00 & 0.40 & 0.13 & 0.00 & 0.33 \\ 0.18 & 0.00 & 0.39 & 0.13 & 0.00 & 0.33\end{array}$

Census controls

Percentage Hispanic

Percentage Black

Log(median household income)

Percentage in poverty

Percentage less than high school education

Percentage high school education

\begin{tabular}{rrrrrr}
0.09 & 0.05 & 0.11 & 0.10 & 0.04 & 0.15 \\
0.13 & 0.08 & 0.14 & 0.11 & 0.05 & 0.15 \\
10.69 & 10.63 & 0.26 & 10.68 & 10.66 & 0.24 \\
0.12 & 0.11 & 0.05 & 0.13 & 0.11 & 0.06 \\
0.20 & 0.19 & 0.07 & 0.20 & 0.18 & 0.08 \\
0.28 & 0.29 & 0.07 & 0.29 & 0.29 & 0.06 \\
\hline
\end{tabular}

NOTE.-This table reports the summary statistics for the sample of members of the House who voted on H.R. 3997 and H.R. 1424. We split the sample based on whether a politician invested in publicly listed financial sector institutions at the beginning of 2008 (Investor in financial sector) or not (Non-investor in financial sector). At the time of the vote on the EESA, the House had one vacant seat.

The ${ }^{\#}$ denotes an indicator variable.

${ }^{\S}$ Positive values denote a loss in net wealth in 2008 and negative values denote a gain in net wealth. 
TABLE 2

Panel A: The Relation Between Personal Wealth InTERests and Voting in FAVor of the Government's Support

\begin{tabular}{|c|c|c|c|c|c|c|c|c|c|c|c|c|c|c|}
\hline & \multicolumn{7}{|c|}{ House Vote on H.R. 3997} & \multicolumn{7}{|c|}{ House Vote on H.R. 1424} \\
\hline & (1) & (2) & $(3)$ & (4) & (5) & (6) & (7) & (8) & (9) & $(10)$ & $(11)$ & $(12)$ & (13) & (14) \\
\hline Personal wealth interest proxy & $\begin{array}{c}1.02 * * * \\
(0.32)\end{array}$ & $\begin{array}{c}1.70 * * * \\
(0.39)\end{array}$ & $\begin{array}{c}0.14 * * * \\
(0.04)\end{array}$ & $\begin{array}{c}0.15^{* * *} \\
(0.04)\end{array}$ & $\begin{array}{c}0.13^{* * * *} \\
(0.05)\end{array}$ & $\begin{array}{c}0.01 * * * \\
(0.00)\end{array}$ & $\begin{array}{l}0.11^{*} \\
(0.06)\end{array}$ & $\begin{array}{l}0.76^{* *} \\
(0.32)\end{array}$ & $\begin{array}{c}1.21 * * * \\
(0.37)\end{array}$ & $\begin{array}{c}0.10^{* * * *} \\
(0.03)\end{array}$ & $\begin{array}{l}0.10^{* *} \\
(0.04)\end{array}$ & $\begin{array}{l}0.09^{*} \\
(0.05)\end{array}$ & $\begin{array}{c}0.00 \\
(0.00)\end{array}$ & $\begin{array}{c}0.05 \\
(0.06)\end{array}$ \\
\hline \multicolumn{15}{|l|}{ Controls for voter interests } \\
\hline Change in mortgage default rates 2005Q4-2007Q4 & $\begin{array}{l}0.10 \dagger \\
(0.06)\end{array}$ & & & & & & & $\begin{array}{c}0.07 \\
(0.06)\end{array}$ & & & & & & \\
\hline Number of financial institutions & $\begin{array}{c}0.12 \\
(0.09)\end{array}$ & $\begin{array}{l}0.18^{*} \\
(0.10)\end{array}$ & $\begin{array}{l}0.16 \# \\
(0.10)\end{array}$ & $\begin{array}{l}0.16 \# \\
(0.10)\end{array}$ & $\begin{array}{l}0.15 \# \\
(0.10)\end{array}$ & $\begin{array}{c}0.16 \\
(0.11)\end{array}$ & $\begin{array}{c}0.14 \\
(0.11)\end{array}$ & $\begin{array}{c}0.10 \\
(0.09)\end{array}$ & $\begin{array}{l}0.21^{*} \\
(0.11)\end{array}$ & $\begin{array}{l}0.20^{*} \\
(0.12)\end{array}$ & $\begin{array}{l}0.20^{*} \\
(0.12)\end{array}$ & $\begin{array}{l}0.20^{*} \\
(0.12)\end{array}$ & $\begin{array}{l}0.21^{*} \\
(0.12)\end{array}$ & $\begin{array}{l}0.21^{*} \\
(0.12)\end{array}$ \\
\hline Fraction of constituency working in financial sector & $\begin{array}{c}0.09 \\
(0.07)\end{array}$ & $\begin{array}{l}0.15^{*} \\
(0.09)\end{array}$ & $\begin{array}{l}0.15^{*} \\
(0.09)\end{array}$ & $\begin{array}{l}0.14 \dagger \\
(0.09)\end{array}$ & $\begin{array}{l}0.13 \dagger \\
(0.09)\end{array}$ & $\begin{array}{l}0.16^{*} \\
(0.09)\end{array}$ & $\begin{array}{c}0.12 \\
(0.09)\end{array}$ & $\begin{array}{c}0.23 * * * \\
(0.08)\end{array}$ & $\begin{array}{c}0.30 * * * \\
(0.10)\end{array}$ & $\begin{array}{c}0.29 * * * \\
(0.10)\end{array}$ & $\begin{array}{c}0.29 * * * \\
(0.10)\end{array}$ & $\begin{array}{c}0.28^{* * * *} \\
(0.10)\end{array}$ & $\begin{array}{c}0.28 * * * \\
(0.10)\end{array}$ & $\begin{array}{c}0.27 * * * \\
(0.10)\end{array}$ \\
\hline Percentage of voters opposing bank bailout & $\begin{array}{c}-0.04 * * * \\
(0.02)\end{array}$ & $\begin{array}{c}-0.04 * * \\
(0.02)\end{array}$ & $\begin{array}{l}-0.04 * \\
(0.02)\end{array}$ & $\begin{array}{l}-0.03 * \\
(0.02)\end{array}$ & $\begin{array}{l}-0.03 \# \\
(0.02)\end{array}$ & $\begin{array}{l}-0.02 \\
(0.02)\end{array}$ & $\begin{array}{l}-0.03 \dagger \\
(0.02)\end{array}$ & $\begin{array}{c}-0.04^{* *} \\
(0.02)\end{array}$ & $\begin{array}{c}-0.05^{* *} \\
(0.02)\end{array}$ & $\begin{array}{c}-0.04 * * \\
(0.02)\end{array}$ & $\begin{array}{c}-0.04 * * \\
(0.02)\end{array}$ & $\begin{array}{c}-0.04 * * \\
(0.02)\end{array}$ & $\begin{array}{l}-0.03 * \\
(0.02)\end{array}$ & $\begin{array}{c}-0.04 * * \\
(0.02)\end{array}$ \\
\hline \multicolumn{15}{|l|}{ Control for special interests } \\
\hline $\log ($ Long term PAC donations by financial sector) & $\begin{array}{c}0.06 \\
(0.05)\end{array}$ & $\begin{array}{c}0.08 \\
(0.07)\end{array}$ & $\begin{array}{c}0.08 \\
(0.07)\end{array}$ & $\begin{array}{c}0.08 \\
(0.07)\end{array}$ & $\begin{array}{c}0.09 \\
(0.06)\end{array}$ & $\begin{array}{l}0.09 \dagger \\
(0.06)\end{array}$ & $\begin{array}{c}0.09 \\
(0.06)\end{array}$ & $\begin{array}{l}0.10^{*} \\
(0.05)\end{array}$ & $\begin{array}{l}0.13^{*} \\
(0.07)\end{array}$ & $\begin{array}{c}0.13 * * \\
(0.07)\end{array}$ & $\begin{array}{c}0.13 * * \\
(0.07)\end{array}$ & $\begin{array}{c}0.14 * * \\
(0.06)\end{array}$ & $\begin{array}{c}0.14 * * \\
(0.06)\end{array}$ & $\begin{array}{c}0.14 * * \\
(0.06)\end{array}$ \\
\hline $\begin{array}{l}\text { Political controls } \\
\text { DW Nominate }\end{array}$ & $\begin{array}{c}0.11 \\
(0.63)\end{array}$ & $\begin{array}{l}-0.07 \\
(0.81)\end{array}$ & $\begin{array}{c}0.05 \\
(0.82)\end{array}$ & $\begin{array}{l}-0.04 \\
(0.80)\end{array}$ & $\begin{array}{l}-0.15 \\
(0.78)\end{array}$ & $\begin{array}{l}-0.12 \\
(0.79)\end{array}$ & $\begin{array}{l}-0.22 \\
(0.79)\end{array}$ & $\begin{array}{c}-0.48 \\
(0.71)\end{array}$ & $\begin{array}{l}-0.51 \\
(0.88)\end{array}$ & $\begin{array}{l}-0.47 \\
(0.88)\end{array}$ & $\begin{array}{l}-0.50 \\
(0.87)\end{array}$ & $\begin{array}{l}-0.56 \\
(0.85)\end{array}$ & $\begin{array}{l}-0.66 \\
(0.87)\end{array}$ & $\begin{array}{l}-0.47 \\
(0.84)\end{array}$ \\
\hline Party affiliation is Republican & $\begin{array}{c}-1.38 * * \\
(0.63)\end{array}$ & $\begin{array}{c}-1.76 * * \\
(0.73)\end{array}$ & $\begin{array}{l}-1.90 * * \\
(0.74)\end{array}$ & $\begin{array}{c}-1.76 * * \\
(0.73)\end{array}$ & $\begin{array}{c}-1.54 * * \\
(0.71)\end{array}$ & $\begin{array}{c}-1.46 * * \\
(0.73)\end{array}$ & $\begin{array}{c}-1.38^{* *} \\
(0.70)\end{array}$ & $\begin{array}{l}-0.70 \\
(0.66)\end{array}$ & $\begin{array}{l}-1.01 \\
(0.79)\end{array}$ & $\begin{array}{l}-1.07 \\
(0.79)\end{array}$ & $\begin{array}{l}-1.03 \\
(0.78)\end{array}$ & $\begin{array}{l}-0.88 \\
(0.76)\end{array}$ & $\begin{array}{l}-0.71 \\
(0.78)\end{array}$ & $\begin{array}{l}-0.89 \\
(0.75)\end{array}$ \\
\hline Number of terms served & $\begin{array}{c}0.08^{* * * *} \\
(0.03)\end{array}$ & $\begin{array}{c}0.10^{* * * *} \\
(0.03)\end{array}$ & $\begin{array}{c}0.09 * * * \\
(0.03)\end{array}$ & $\begin{array}{c}0.09 * * * \\
(0.03)\end{array}$ & $\begin{array}{c}0.09 * * * \\
(0.03)\end{array}$ & $\begin{array}{c}0.11 * * * \\
(0.03)\end{array}$ & $\begin{array}{c}0.09 * * * \\
(0.03)\end{array}$ & $\begin{array}{c}0.03 \\
(0.03)\end{array}$ & $\begin{array}{l}0.05 \# \\
(0.03)\end{array}$ & $\begin{array}{c}0.05 \\
(0.03)\end{array}$ & $\begin{array}{c}0.05 \\
(0.03)\end{array}$ & $\begin{array}{c}0.05 \\
(0.03)\end{array}$ & $\begin{array}{c}0.05 \\
(0.03)\end{array}$ & $\begin{array}{c}0.04 \\
(0.03)\end{array}$ \\
\hline Finance committee member & $\begin{array}{c}0.07 \\
(0.29)\end{array}$ & $\begin{array}{c}0.05 \\
(0.35)\end{array}$ & $\begin{array}{c}0.02 \\
(0.35)\end{array}$ & $\begin{array}{c}0.07 \\
(0.35)\end{array}$ & $\begin{array}{c}0.05 \\
(0.34)\end{array}$ & $\begin{array}{c}0.05 \\
(0.37)\end{array}$ & $\begin{array}{c}0.07 \\
(0.35)\end{array}$ & $\begin{array}{l}-0.32 \\
(0.31)\end{array}$ & $\begin{array}{l}-0.49 \\
(0.35)\end{array}$ & $\begin{array}{l}-0.50 \\
(0.35)\end{array}$ & $\begin{array}{l}-0.48 \\
(0.35)\end{array}$ & $\begin{array}{l}-0.49 \\
(0.35)\end{array}$ & $\begin{array}{l}-0.58 \# \\
(0.38)\end{array}$ & $\begin{array}{l}-0.58 \# \\
(0.35)\end{array}$ \\
\hline Post Congress work in finance sector & $\begin{array}{c}0.14 \\
(0.34)\end{array}$ & $\begin{array}{c}0.10 \\
(0.42)\end{array}$ & $\begin{array}{c}0.17 \\
(0.40)\end{array}$ & $\begin{array}{c}0.20 \\
(0.41)\end{array}$ & $\begin{array}{c}0.29 \\
(0.41)\end{array}$ & $\begin{array}{c}0.28 \\
(0.41)\end{array}$ & $\begin{array}{c}0.25 \\
(0.40)\end{array}$ & $\begin{array}{c}0.04 \\
(0.38)\end{array}$ & $\begin{array}{c}0.25 \\
(0.45)\end{array}$ & $\begin{array}{c}0.29 \\
(0.44)\end{array}$ & $\begin{array}{c}0.32 \\
(0.45)\end{array}$ & $\begin{array}{c}0.37 \\
(0.44)\end{array}$ & $\begin{array}{c}0.35 \\
(0.44)\end{array}$ & $\begin{array}{c}0.42 \\
(0.44)\end{array}$ \\
\hline Not running for reelection & $\begin{array}{c}2.81 * * * \\
(0.76)\end{array}$ & $\begin{array}{c}3.82 * * * \\
(1.12)\end{array}$ & $\begin{array}{c}3.75 * * * \\
(1.09)\end{array}$ & $\begin{array}{c}3.80^{* * * *} \\
(1.20)\end{array}$ & $\begin{array}{c}3.39 * * * \\
(1.22)\end{array}$ & $\begin{array}{c}3.79 * * * \\
(1.10)\end{array}$ & $\begin{array}{c}3.24 * * * \\
(1.08)\end{array}$ & $\begin{array}{c}2.59 * * * \\
(0.81)\end{array}$ & $\begin{array}{c}2.87 * * * \\
(0.89)\end{array}$ & $\begin{array}{c}2.82 * * * \\
(0.88)\end{array}$ & $\begin{array}{c}2.89 * * * \\
(0.95)\end{array}$ & $\begin{array}{c}2.68 * * * \\
(0.94)\end{array}$ & $\begin{array}{c}2.52 * * * \\
(0.88)\end{array}$ & $\begin{array}{c}2.57 * * * \\
(0.86)\end{array}$ \\
\hline Equity investor in non-financial sector & $\begin{array}{l}-0.32 \\
(0.29)\end{array}$ & $\begin{array}{c}-0.85^{* *} \\
(0.34)\end{array}$ & $\begin{array}{c}-0.77 * * \\
(0.33)\end{array}$ & $\begin{array}{l}-0.60^{*} \\
(0.32)\end{array}$ & $\begin{array}{c}-1.06^{* *} \\
(0.48)\end{array}$ & $\begin{array}{l}-0.09 \\
(0.28)\end{array}$ & $\begin{array}{l}-0.06 \\
(0.28)\end{array}$ & $\begin{array}{l}-0.03 \\
(0.29)\end{array}$ & $\begin{array}{l}-0.30 \\
(0.33)\end{array}$ & $\begin{array}{l}-0.22 \\
(0.33)\end{array}$ & $\begin{array}{l}-0.12 \\
(0.33)\end{array}$ & $\begin{array}{l}-0.37 \\
(0.50)\end{array}$ & $\begin{array}{c}0.32 \\
(0.28)\end{array}$ & $\begin{array}{c}0.28 \\
(0.29)\end{array}$ \\
\hline Percentage Hispanic & $\begin{array}{c}-4.20 * * \\
(1.88)\end{array}$ & $\begin{array}{c}-6.16^{* *} \\
(2.57)\end{array}$ & $\begin{array}{c}-6.47 * * \\
(2.56)\end{array}$ & $\begin{array}{c}-6.50^{* * * *} \\
(2.51)\end{array}$ & $\begin{array}{c}-6.32 * * * \\
(2.43)\end{array}$ & $\begin{array}{c}-6.97 * * * \\
(2.68)\end{array}$ & $\begin{array}{c}-6.58 * * \\
(2.63)\end{array}$ & $\begin{array}{c}-4.13 * * \\
(1.62)\end{array}$ & $\begin{array}{l}-4.42 * * \\
(2.14)\end{array}$ & $\begin{array}{l}-4.52 * * \\
(2.15)\end{array}$ & $\begin{array}{c}-4.56^{* *} \\
(2.13)\end{array}$ & $\begin{array}{c}-4.50 * * \\
(2.09)\end{array}$ & $\begin{array}{c}-4.55^{* *} \\
(2.32)\end{array}$ & $\begin{array}{l}-4.20^{*} \\
(2.23)\end{array}$ \\
\hline Percentage Black & $\begin{array}{c}-4.33 * * * \\
(1.28)\end{array}$ & $\begin{array}{c}-7.19 * * * \\
(1.86)\end{array}$ & $\begin{array}{c}-7.42 * * * \\
(1.87)\end{array}$ & $\begin{array}{c}-7.46^{* * *} \\
(1.85)\end{array}$ & $\begin{array}{c}-7.53 * * * \\
(1.86)\end{array}$ & $\begin{array}{c}-7.08 * * * \\
(2.05)\end{array}$ & $\begin{array}{c}-6.19 * * * \\
(1.93)\end{array}$ & $\begin{array}{l}-2.92 * \\
(1.50)\end{array}$ & $\begin{array}{c}-4.26^{* *} \\
(2.03)\end{array}$ & $\begin{array}{l}-4.41 * * \\
(2.03)\end{array}$ & $\begin{array}{c}-4.45^{* *} \\
(2.01)\end{array}$ & $\begin{array}{c}-4.44 * * \\
(2.00)\end{array}$ & $\begin{array}{c}-5.11 * * \\
(2.27)\end{array}$ & $\begin{array}{c}-3.72 * \\
(2.10)\end{array}$ \\
\hline Percentage living in urban environment & $\begin{array}{c}0.30 \\
(0.94)\end{array}$ & $\begin{array}{c}1.86 \\
(1.37)\end{array}$ & $\begin{array}{l}1.96 \dagger \\
(1.36)\end{array}$ & $\begin{array}{l}1.97 \dagger \\
(1.35)\end{array}$ & $\begin{array}{l}2.48^{*} \\
(1.36)\end{array}$ & $\begin{array}{c}1.89 \\
(1.40)\end{array}$ & $\begin{array}{c}1.76 \\
(1.37)\end{array}$ & $\begin{array}{c}1.31 \\
(0.96)\end{array}$ & $\begin{array}{l}2.37^{*} \\
(1.41)\end{array}$ & $\begin{array}{l}2.40^{*} \\
(1.41)\end{array}$ & $\begin{array}{l}2.41^{*} \\
(1.41)\end{array}$ & $\begin{array}{l}2.67^{*} \\
(1.40)\end{array}$ & $\begin{array}{l}2.26 \dagger \\
(1.39)\end{array}$ & $\begin{array}{c}1.98 \\
(1.40)\end{array}$ \\
\hline Log(median household income) & $2.76^{*}$ & $7.47 * * *$ & $7.49 * * *$ & $7.35 * * *$ & $7.58^{* * *}$ & $8.06^{* * *}$ & $7.27^{* * *}$ & $3.54 * *$ & $6.98^{* * *}$ & $6.86^{* * * *}$ & $6.75^{* * * *}$ & $6.76^{* * *}$ & $6.78 * * *$ & $6.70^{* * *}$ \\
\hline
\end{tabular}




\begin{tabular}{|c|c|c|c|c|c|c|c|c|c|c|c|c|c|c|}
\hline & $(1.46)$ & $(2.35)$ & $(2.35)$ & $(2.31)$ & $(2.22)$ & $(2.36)$ & $(2.31)$ & $(1.53)$ & $(2.42)$ & $(2.42)$ & $(2.38)$ & $(2.37)$ & $(2.44)$ & $(2.35)$ \\
\hline Percentage in poverty & $20.44 * * *$ & $42.24 * * *$ & $42.70^{* * *}$ & $41.92 * * *$ & $43.31 * * *$ & $46.00 * * *$ & $40.48 * * *$ & $\begin{array}{c}25.00 * * * \\
(859)\end{array}$ & $39.20 * * *$ & $39.00^{* * * *}$ & $38.49 * * *$ & $39.34 * * *$ & $40.34 * * *$ & $\begin{array}{c}37.97 * * * \\
(1287\end{array}$ \\
\hline Percentage less than high school education & $\begin{array}{l}(7.58) \\
-0.55 \\
(3.54)\end{array}$ & $\begin{array}{l}(11.84) \\
-1.21 \\
(4.98)\end{array}$ & $\begin{array}{c}(11.88) \\
-0.74 \\
(4.95)\end{array}$ & $\begin{array}{c}(11.61) \\
-0.37 \\
(4.86)\end{array}$ & $\begin{array}{c}(11.45) \\
-0.47 \\
(4.73)\end{array}$ & $\begin{array}{c}(11.10) \\
0.65 \\
(5.03)\end{array}$ & $\begin{array}{c}(11.81) \\
0.49 \\
(5.01)\end{array}$ & $\begin{array}{l}(8.59) \\
-0.16 \\
(3.67)\end{array}$ & $\begin{array}{c}(12.98) \\
-1.42 \\
(4.99)\end{array}$ & $\begin{array}{l}(13.01) \\
-1.35 \\
(4.93)\end{array}$ & $\begin{array}{l}(12.85) \\
-1.14 \\
(4.87)\end{array}$ & $\begin{array}{c}(12.88) \\
-1.48 \\
(4.73)\end{array}$ & $\begin{array}{c}(13.02) \\
-1.89 \\
(4.81)\end{array}$ & $\begin{array}{c}(12.82) \\
-1.45 \\
(4.81)\end{array}$ \\
\hline Percentage high school education & $\begin{array}{c}3.36 \\
(3.27)\end{array}$ & $\begin{array}{c}17.23 * * * \\
(6.53)\end{array}$ & $\begin{array}{c}16.76^{* * *} \\
(6.47)\end{array}$ & $\begin{array}{c}15.99 * * \\
(6.34)\end{array}$ & $\begin{array}{c}16.93 * * * \\
(6.17)\end{array}$ & $\begin{array}{c}14.46^{* *} \\
(6.63)\end{array}$ & $\begin{array}{c}13.51^{* *} \\
(6.22)\end{array}$ & $\begin{array}{c}5.19 \\
(3.67)\end{array}$ & $\begin{array}{c}14.56 * * \\
(6.92)\end{array}$ & $\begin{array}{c}14.02 * * \\
(6.82)\end{array}$ & $\begin{array}{c}13.54 * * \\
(6.71)\end{array}$ & $\begin{array}{c}13.49 * * \\
(6.63)\end{array}$ & $\begin{array}{l}12.23 * \\
(6.78)\end{array}$ & $\begin{array}{l}11.77^{*} \\
(6.66)\end{array}$ \\
\hline State fixed effects & Excluded & Included & Included & Included & Included & Included & Included & Excluded & Included & Included & Included & Included & Included & Included \\
\hline Observations & 433 & 405 & 405 & 405 & 405 & 379 & 390 & 434 & 411 & 411 & 411 & 411 & 385 & 396 \\
\hline Chi-squared & 91.47 & 128.8 & 127.5 & 127 & 118.7 & 119.2 & 109.9 & 90.21 & 133.1 & 129.5 & 129 & 119.4 & 110 & 112.2 \\
\hline p-value & 0.00 & 0.00 & 0.00 & 0.00 & 0.00 & 0.00 & 0.00 & 0.00 & 0.00 & 0.00 & 0.00 & 0.00 & 0.00 & 0.00 \\
\hline
\end{tabular}

Note.-This table reports politician-level logit regressions on the vote in favor of H.R. 3997 (columns 1-7) and in favor of H.R. 1424 (columns 8-14) for measures of the sensitivity of personal wealth interests to the financial sector. Specifically, columns 1 and 2, as well as 8 and 9 report on the regressions using "investor in financial sector", columns 3 and 10 use "Log(Equity investment in financial sector)", columns 4 and 11 use "Log(Expected losses due to investment in financial sector)", columns 5 and 12 use " $\log ($ Expected losses due to participation in stock market)", columns 6 and 13 use "Percentage loss in net wealth in 2008", and finally columns 7 and 14 use "Log(Net wealth at the beginning of 2009)". In columns 6-7 and in 13-14, we drop politicians who have a negative net wealth in 2008. We also dropped on representative who did not vote on H.R. 3997. Except for columns 1 and 8, all models contain state fixed effects. Robust standard errors are included in parentheses below the coefficient estimates.

$\dagger$ Significant at $15 \%$.

* Significant at $10 \%$.

** Significant at 5\%.

*** Significant at $1 \%$. 
B. VOTING IN FAVOR OF GOVERNMENT'S SUPPORT CONTROLLING FOR INVESTMENT-PAC SENSITIVITY AND USING ALTERNATIVE VOTER SUPPORT MEASURES

\begin{tabular}{|c|c|c|c|c|c|c|c|c|}
\hline & \multicolumn{4}{|c|}{ House Vote on H.R. 3997} & \multicolumn{4}{|c|}{ House Vote on H.R. 1424} \\
\hline & $(1)$ & $(2)$ & $(3)$ & $(4)$ & $(5)$ & $(6)$ & $(7)$ & $(8)$ \\
\hline Investor in financial sector & & $\begin{array}{c}1.77 * * * \\
(0.45)\end{array}$ & $\begin{array}{c}0.96 * * * \\
(0.32)\end{array}$ & $\begin{array}{c}0.96 * * * \\
(0.32)\end{array}$ & & $\begin{array}{c}1.38 * * * \\
(0.44)\end{array}$ & $\begin{array}{c}0.72 * * \\
(0.32)\end{array}$ & $\begin{array}{c}0.72 * * \\
(032)\end{array}$ \\
\hline Investment-PAC sensitivity & $\begin{array}{l}0.73 * \\
(0.43)\end{array}$ & $\begin{array}{l}-0.17 \\
(0.53)\end{array}$ & & & $\begin{array}{c}0.38 \\
(0.43)\end{array}$ & $\begin{array}{l}-0.41 \\
(0.54)\end{array}$ & & \\
\hline Pre-crisis opinion on government handling of Wall Street problems ${ }^{1}$ & & & $\begin{array}{c}0.28 \\
(0.77)\end{array}$ & & & & $\begin{array}{l}-0.32 \\
(0.75)\end{array}$ & \\
\hline Pre-crisis opinion on bailout good or bad thing ${ }^{2}$ & & & & $\begin{array}{c}0.03 \\
(0.92)\end{array}$ & & & & $\begin{array}{c}-0.31 \\
(0.93)\end{array}$ \\
\hline Controls for voter and special interests & Included & Included & Included & Included & Included & Included & Included & Included \\
\hline Political controls & Included & Included & Included & Included & Included & Included & Included & Included \\
\hline Census controls & Included & Included & Included & Included & Included & Included & Included & Included \\
\hline State fixed effects & Included & Included & Excluded & Excluded & Included & Included & Excluded & Excluded \\
\hline Observations & 405 & 405 & 429 & 429 & 411 & 411 & 430 & 430 \\
\hline Chi-squared & 119.84 & 129.6 & 93.31 & 83.65 & 120.31 & 134.06 & 80.18 & 79.93 \\
\hline$p$-value & 0.00 & 0.00 & 0.00 & 0.00 & 0.00 & 0.00 & 0.00 & 0.00 \\
\hline
\end{tabular}

Note: This panel reports on variations of the main specification to explain the House vote on the EESA. In columns (1) and (5) we add the Tahoun Investment-PAC sensitivity proxy to the set of control variables, but drop the variable of interest (Investor in financial sector). In columns (2) and (6) we include the Tahoun proxy together with the variable of interests. Columns (3-4) and (7-8) replace the Percentage of voters opposing bank bailout by two alternative measures of voter opposition based on surveys conducted before the vote. Robust standard errors are reported in parentheses. Pew survey questions used to construct Voter Support Measures:

${ }^{1}$ Based on what you have read and heard, do you think that the government is doing an excellent, good, only fair or poor job of handling the financial problems of Wall Street? $(1=$ excellent, $4=$ poor $)$

${ }^{2}$ As you may know, the government is potentially investing billions to try and keep financial institutions and markets secure. Do you think this is the right thing or the wrong thing for the government to be doing? (1=right, $2=$ wrong)

* Significant at $10 \%$.

** Significant at $5 \%$.

$* * *$ Significant at $1 \%$. 
TABLE 3

ENDOGENOUS ASSET HOLDINGS AND UNOBSERVED PREFERENCES FOR THE FINANCIAL SECTOR

A. PROXIES FOR POLITICIANS’ UNOBSERVED PREFERENCES

\begin{tabular}{|c|c|c|c|c|c|c|c|c|c|c|}
\hline & \multicolumn{5}{|c|}{ HOUSE VOTE ON H.R. 3997} & \multicolumn{5}{|c|}{ HOUSE VOTE ON H.R. 1424} \\
\hline & $(1)$ & $(2)$ & (3) & $(4)$ & $(5)$ & $(6)$ & $(7)$ & $(8)$ & $(9)$ & $(10)$ \\
\hline Investor in financial sector & $\begin{array}{c}1.84 * * * \\
(0.41)\end{array}$ & $\begin{array}{c}1.71 * * * \\
(0.40)\end{array}$ & $\begin{array}{c}1.70 * * * \\
(0.39)\end{array}$ & $\begin{array}{c}1.70 * * * \\
(0.39)\end{array}$ & $\begin{array}{c}1.86 * * * \\
(0.41)\end{array}$ & $\begin{array}{c}1.34 * * * \\
(0.38)\end{array}$ & $\begin{array}{c}1.19 * * * \\
(0.36)\end{array}$ & $\begin{array}{l}1.18 * * * \\
(0.37)\end{array}$ & $\begin{array}{l}1.21 * * * \\
(0.37)\end{array}$ & $\begin{array}{c}1.30 * * * \\
(0.39)\end{array}$ \\
\hline Ex-investor in financial sector & $\begin{array}{c}0.47 \\
(0.46)\end{array}$ & & & & $\begin{array}{c}0.51 \\
(0.47)\end{array}$ & $\begin{array}{c}0.48 \\
(0.41)\end{array}$ & & & & $\begin{array}{c}0.41 \\
(0.43)\end{array}$ \\
\hline $\begin{array}{l}\text { Previous employment in financial } \\
\text { sector }\end{array}$ & & $\begin{array}{l}-0.21 \\
(0.41)\end{array}$ & & & $\begin{array}{l}-0.23 \\
(0.42)\end{array}$ & & $\begin{array}{c}0.11 \\
(0.43)\end{array}$ & & & $\begin{array}{c}0.02 \\
(0.44)\end{array}$ \\
\hline $\begin{array}{l}\text { Finance or economics-related } \\
\text { education }\end{array}$ & & & $\begin{array}{c}0.06 \\
(0.38)\end{array}$ & & $\begin{array}{c}0.10 \\
(0.39)\end{array}$ & & & $\begin{array}{c}0.47 \\
(0.40)\end{array}$ & & $\begin{array}{c}0.51 \\
(0.41)\end{array}$ \\
\hline Finance committee member & & & & $\begin{array}{c}0.05 \\
(0.35)\end{array}$ & $\begin{array}{c}0.11 \\
(0.36)\end{array}$ & & & & $\begin{array}{l}-0.49 \\
(0.35)\end{array}$ & $\begin{array}{c}-0.43 \\
(0.36)\end{array}$ \\
\hline Voter interest controls & Included & Included & Included & Included & Included & Included & Included & Included & Included & Included \\
\hline Special interest controls & Included & Included & Included & Included & Included & Included & Included & Included & Included & Included \\
\hline Political controls ${ }^{\#}$ & Included & Included & Included & Included & Included & Included & Included & Included & Included & Included \\
\hline Census controls & Included & Included & Included & Included & Included & Included & Included & Included & Included & Included \\
\hline State fixed effects & Included & Included & Included & Included & Included & Included & Included & Included & Included & Included \\
\hline Observations & 405 & 405 & 405 & 405 & 405 & 411 & 411 & 411 & 411 & 411 \\
\hline Chi-squared & 128.8 & 129.1 & 128.7 & 128.8 & 129 & 132 & 132 & 133.8 & 133.1 & 137.7 \\
\hline$p$-value & 0.00 & 0.00 & 0.00 & 0.00 & 0.00 & 0.00 & 0.00 & 0.00 & 0.00 & 0.00 \\
\hline
\end{tabular}

Robust standard errors are in parentheses.

$* * *, * *, *$, denotes significant at the $10 \%, 5 \%$, and $1 \%$ levels respectively.

${ }^{\#}$ Political controls do not include the finance committee member variable. 


\begin{tabular}{lccc}
\hline \hline & \multicolumn{3}{c}{$\begin{array}{r}\text { SUMMARY STATISTICS ON SAMPLE OF SPOUSES OF MEMBERS OF } \\
\text { THE HOUSE WITH DC PLAN (N = 84) }\end{array}$} \\
\cline { 2 - 4 } & Mean & Median & $\begin{array}{c}\text { Standard } \\
\text { Deviation }\end{array}$ \\
\cline { 2 - 4 } $\begin{array}{l}\text { Return on spousal DC plan } \\
\text { Negative return on spousal DC } \\
\text { plan }^{\#}\end{array}$ & 0.12 & 0.00 & 0.28 \\
\hline
\end{tabular}

\section{EXOGENOUS VARIATION IN POLITICIANS' WEALTH}

\begin{tabular}{|c|c|c|c|c|}
\hline & \multicolumn{4}{|c|}{$\begin{array}{l}\text { LOGIT } \\
\end{array}$} \\
\hline & \multicolumn{2}{|c|}{ H.R. 3997} & \multicolumn{2}{|c|}{ H.R. 1424} \\
\hline & $(1)$ & $(2)$ & (3) & (4) \\
\hline Return on spousal DC plan ${ }^{\S}$ & $\begin{array}{c}3.90 * * * \\
(1.33)\end{array}$ & & $\begin{array}{l}2.74 \dagger \\
(1.78)\end{array}$ & \\
\hline Negative return on spousal DC plan & & $\begin{array}{l}1.47 * \\
(0.75)\end{array}$ & & $\begin{array}{l}1.63^{*} \\
(0.85)\end{array}$ \\
\hline Controls & Included & Included & Included & Included \\
\hline State fixed effects & Excluded & Excluded & Excluded & Excluded \\
\hline Observations & 84 & 84 & 81 & 81 \\
\hline Chi-squared & 21.47 & 15.31 & 22.97 & 26.14 \\
\hline$p$-value & 0.43 & 0.81 & 0.29 & 0.16 \\
\hline
\end{tabular}

NOTE.-This table reports politician-level logit regressions on the vote in favor of H.R. 3997 and on the vote in favor of H.R. 1424 for the sensitivity of personal wealth interests to the financial sector. The regressions in panel A control for the variables intended to capture the politicians' unobserved preferences for the financial sector. In panels B and C, we use a sub sample of politicians whose spouses participated in Defined Contribution plans. Conditional on participation, we use the 2008 annual return on the IRA plan multiplied by -1 and an indicator variable that equals one if the annual return on the spousal IRA plan was negative in 2008 as a source of exogenous variation in the politician's wealth sensitivity to the financial sector. All models include the full set of controls from table 2. Robust standard errors are included in parentheses below the coefficient estimates.

$\uparrow$ Significant at $15 \%$.

* Significant at $10 \%$.

** Significant at $5 \%$.

$* * *$ Significant at $1 \%$.

The ${ }^{\#}$ denotes an indicator variable.

${ }^{\S}$ Positive values denote a loss (i.e., negative returns) in 2008 and negative values denote a gain. 


\begin{tabular}{|c|c|c|c|c|}
\hline \multirow{3}{*}{$\begin{array}{l}\text { Personal wealth proxy: } \\
\text { Investor in financial sector }\end{array}$} & \multicolumn{2}{|c|}{ HOUSE VOTE ON H.R. 3997} & \multicolumn{2}{|c|}{ HOUSE VOTE ON H.R. 1424} \\
\hline & Party affiliation & DW-Nominate & Party affiliation & DW-Nominate \\
\hline & (1) & (2) & (3) & (4) \\
\hline ATE & $\begin{array}{c}0.116^{* *} \\
(0.06)\end{array}$ & $\begin{array}{c}0.131 * * \\
(0.06)\end{array}$ & $\begin{array}{l}0.096^{*} \\
(0.05)\end{array}$ & $\begin{array}{c}0.105^{* *} \\
(0.05)\end{array}$ \\
\hline Observations & 433 & 433 & 434 & 434 \\
\hline $\begin{array}{l}\text { Additional matching } \\
\text { variables }\end{array}$ & $\begin{array}{l}\text { PAC donations, } \\
\text { Voter opposition against } \\
\text { bailout }\end{array}$ & $\begin{array}{c}\text { PAC donations, } \\
\text { Voter opposition against } \\
\text { bailout }\end{array}$ & $\begin{array}{l}\text { PAC donations, } \\
\text { Voter opposition against } \\
\text { bailout }\end{array}$ & $\begin{array}{l}\text { PAC donations, } \\
\text { Voter opposition against } \\
\text { bailout }\end{array}$ \\
\hline Exact match & Yes & No & Yes & No \\
\hline
\end{tabular}

Note: This table presents nearest neighborhood matching average treatment effect estimates (Abadie and Imbens, 2006; Abadie and Imbens 2011) of the preferred measure of personal wealth onto the vote on H.R. 3997 and on H.R. 1424. Politicians are matched based on the campaign donations from financial institutions and on the degree of voter opposition against the EESA in their district. In Column (1), we present the biascorrected average treatment effect estimate when we also perform an exact match on Party affiliation of the politician. Column (2) presents the treatment effect when matching on the DW-Nominate measure of a given politician's ideology. Inferences are based on robust Abadie-Imbens standard errors. 
TABLE 4

RELATIVE IMPORTANCE OF PERSONAL WEALTH INTEREST COMPARED With CONSTITUENCY AND SPECIAL INTERESTS

\section{DIFFERENTIAL MARGINAL EFFECT}

INVESTOR VS. NON-INVESTOR

\section{H.R. 3997}

H.R. 1424

\section{A. VOTER OPPOSITION ONLY}

\begin{tabular}{lcc} 
Q1:Low & $0.25^{* * *}$ & $0.15^{* *}$ \\
& $(0.09)$ & $(0.07)$ \\
Q2-Q3: Moderate & $0.14^{*}$ & 0.07 \\
& $(0.09)$ & $(0.07)$ \\
Q4: High & $0.23^{* *}$ & $0.23 * *$ \\
& $(0.11)$ & $(0.10)$ \\
\hline
\end{tabular}

B. VOTER OPPOSITION AND FINANCIAL SECTOR CAMPAIGN DONATIONS

Low Opposition, Low PAC

$0.18^{*}$

Low Opposition, High PAC

$(0.09)$

$(0.09)$

$0.16^{*}$

$0.14 *$

$(0.09)$

$(0.07)$

High Opposition, Low PAC

$0.25 * *$

$0.21^{*}$

High Opposition, High PAC

$(0.11)$

$(0.11)$

0.15

0.15

(0.10)

(0.09)

NOTE.-This table presents the average marginal effects of a given politician holding assets in the financial sector (or not) on the propensity to vote in favor of EESA. In panel A, the marginal effect is computed by conditioning on the percentage of voter opposition against EESA in the member's congressional district. Q1-Q4 represent quarters of the empirical distribution of the voter opposition. In panel B, the differential marginal effect of holding assets in the financial sector is conditioned on (1) above median voter opposition and (2) above median campaign donations by financial sector, which generates four possible permutations of strength of incentives deriving from voter opposition and campaign donations. Robust standard errors are reported below the marginal effects estimates in parentheses.

* Significant at $10 \%$.

** Significant at 5\%.

*** Significant at $1 \%$. 